\title{
Duygusal Emek ile İşe Yabancılaşma İlişkisinde Psikolojik Sermayenin Düzenleyici Rolü ${ }^{1}$
}

\author{
DOI: 10.26466/opus.544850 \\ * \\ Hüseyin Aslan ${ }^{*}$ - İbrahim Sani Mert** \\ * Dr.Öğr.Üyesi, Osmaniye Korkut Ata Üniversitesi/ Osmaniye / Türkiye \\ E-Posta: huseyinaslan111@gmail.com \\ ORCID: $\underline{0000-0002-0547-1317}$ \\ ** Prof. Dr., Antalya Bilim Üniversitesi/ Antalya/ Türkiye \\ E-Posta: $\underline{\text { ibrahim.mert@antalya.edu.tr }}$ \\ ORCID: $\underline{0000-0002-2850-1865}$
}

\section{Öz}

Turizm işletmelerinde ürün ve hizmetlerin üretildiği anda tüketilmesi özelliği çalışanlar ile müşteriler arasında etkileşim yaşanmasına neden olmaktadır. Bu etkileşimde çalışanların müşterilere davranışları aracılığıyla olumlu veya olumsuz duygularını yansıtmaları müşterilerin çalışan veya işletme hakkında belirli bir izlenim elde etmesine neden olmakta ve bu durum ise işletmelerin hizmet kalitesini etkilemektedir. Hizmet sektöründe duyguların müşteri etkileşiminde belirleyici bir etken olması sonucu işletmeler; hizmet kalitesinin arttırılması için çalışanlarından fiziksel ve zihinsel çabalarının yanı sıra üretim sürecinde duygusal emeklerini sunmaların beklemektedirler. Bu çalışmanın amacı, müşteri memnuniyetinin rekabette kilit rol oynadığı sektörlerin başında gelen otelcilik sektöründe yer alan şehir otelleri çalışanlarının katılımı ile duygusal emek ile işe yabancılaşma ilişkisinde psikolojik sermayenin düzenleyici etkisinin bulunup bulunmadı̆̆ araştırmaktır. Bu maksatla, Gaziantep, Adana ve Osmaniye illerinde şehir otellerinde çalışan 549 katılımoıdan anket aracılığıyla veri toplanmıştır. Verilerin analizinde, keşfedici ve doğrulayıcı faktör analizleri yapılmış, değişkenler arası korelasyonlar tespit edilmiş ve yapısal eşitlik modeli ile modelin uyum iyiliği testleri ve regresyon analizi yapılmıştır. Yapılan analizler neticesinde, duygusal emeğin psikolojik sermayeyi negatif yönde anlaml olarak etkilediği ve işe yabancılaşmayı ise pozitif yönde anlamlı olarak etkilediği tespit edilmiş, psikolojik sermayenin ise işe yabancılaşmayı negatif yönde anlamlı olarak etkilediğ̈i tespit edilmiştir. Ayrıca düzenleyici analiz neticesinde çalışanların sahip oldukları psikolojik sermayenin duygusal emek ile işe yabancılaşma arasındaki ilişkide düzenleyici bir rol üstlendiği tespit edilmiştir.

Anahtar Kelimeler: Duygusal emek, işe yabancılaşma, psikolojik sermaye

\footnotetext{
${ }^{1}$ Bu çalışma Hasan Kalyoncu Üniversitesinde SBE'de 2018 yılında yapılmış olan doktora tezinden türetilmiştir.
} 


\title{
The Moderating Role of Psychological Capital in The Relationship Between Emotional Labor and Work Alienation
}

\begin{abstract}
The fact that the products and services are consumed at the moment when they are produced in tourism enterprises causes interaction between employees and customers. In this interaction, reflecting positive or negative feelings of the employees through their behaviors towards the customers causes customers to get a certain impression about the employee or the business and this affects the service quality of the enterprises. As a result of emotions in service sector as a determinant factor in customer interaction; In addition to their physical and mental efforts, they expect their employees to present their emotional efforts in the production process in order to increase the quality of service. The purpose of this study is to investigate whether there is a moderating effect of psychological capital in the relationship between emotional labor and work alienation with the participation of city hotels employees in the hotel sector, which is one of the sectors where customer satisfaction plays a key role in the competition. For this purpose, data were collected from 549 participants working in city hotels in Gaziantep, Adana and Osmaniye. In the analysis of the data, exploratory and confirmatory factor analyzes were made, correlations between variables were determined, and the model's goodness of fit model and regression analysis were performed with structural equation model. As a result of the analyzes, it has been determined that emotional labor has a significant negative effect on psychological capital and has a positive effect on work alienation. Additionally, psychological capital has been found to have a significant negative effect on work alienation. In addition, as a result of the moderating analysis, it was found that the psychological capital had a moderating role in the relationship between emotional labor and work alienation.
\end{abstract}

Keywords: Emotional labor, work alienation, psychological capital 


\section{Giriş}

Küreselleşmenin etkisiyle günümüz bilgi ve iletişim teknolojisindeki gelişmeler yoğun rekabet ortamının yaşanmasına neden olmuştur. Bilgi ve iletişim sektöründe yaşanan olumlu gelişmeler yoğun rekabet ortamında hizmet sektörü işletmelerini yenilikçi stratejiler geliştirmeye yönlendirmiştir (Türk ve Kara, 2018). Rekabet avantajı sağlamak amacıyla hizmet sektöründeki bazı iş kollarında (sağlık, bankacılık, eğitim) olduğu gibi turizm sektöründe de yenilikçi gelişmeler işletmelere birtakım kolaylıklar sağlamıştır (Kızanlıklı, 2014).

Teknolojik gelişimler turizm işletmelerine birtakım kolaylıklar sağlasa da müşteri memnuniyeti noktasında yetersiz kalmaktadır. Dolayısıyla, müşteri memnuniyeti noktasında rakiplerine karşı rekabet avantajı elde etmek isteyen turizm işletmelerinin hizmet kalitesini yükseltmesi gerekmektedir. İşletmelerin bu durumu sağlayabilmesi için sahip oldukları insan kaynağını etkin bir şekilde yönetebilmeleri gerekmektedir. İnsan kaynağının etkinliğinin arttırılabilmesi için ise işletmeler, çalışanların psikolojik durumlarını iyileştirmeye çalışmalı, mevcut potansiyellerinin ortaya çıkartılması için gerekli fırsatları tanımalılar ve sahip oldukları özellik ve yetenekleri geliştirmeye çalışmalılardır (Beğenirbaş ve Turgut, 2016: 58). Bu nedenle, duygusal emek, işe yabancılaşma ve psikolojik sermaye kavramları çalışma yaşamında öne çıkmaktadır.

Duyguların müşteri etkileşiminde belirleyici bir etken olması fiziksel ve zihinsel çabanın yanı sıra üretim sürecinde yeni bir kaynak oluşturmuştur. Çalışanların müşteri ile olan etkileşiminde sergilemiş oldukları davranışların belirli bir duyguyla ifade edilmiş olması çalışma yaşamında duygunun önemini arttırmıştır (Tokmak, 2014). Çalışanlar yüz yüze kurdukları iletişimde müşterilere davranışları aracılığıyla belirli duygular yansıtmaktadırlar. Bu duyguların olumlu veya olumsuz olması doğrudan müşterinin çalışan veya işletme üzerinde belirli bir izlenim elde etmesini sağlamaktadır. Müşterilerde olumsuz bir izlenim bırakmak istemeyen işletmeler çalışanların davranışlarını kontrol altına almaya ve işletmenin önceden belirlemiş oldukları kurallara göre davranış sergilemelerini istemektedir. Çalışanlar ise kendilerinden istenen davranışları sergilemek için belirli bir çaba harcamak durumdadırlar. Duyguların belirli bir 
çabayla sergilenmesi durumu ise "duygusal emek" kavramını doğurmuştur (Hochschild,1983; Ashforth ve Humphrey, 1993).

Bir duygu yönetim süreci olan duygusal emek, çalışanların duygularını önceden belirlenmiş kurallara göre denetleyerek müşteriye sunması olarak tanımlanmıştır (Hochschild, 1983: 7). Duygusal emeği, duyguların ticarileşip bir ücret için satılması olarak yorumlayan Hochschild (1983) duygusal emeği, hizmetin bir sahne, müşterinin seyirci ve çalışanın ise belirli roller üstlendiği bir oyun olarak görmüştür. Oysa iş yaşamının bir sahne olmadığı çok aşikardır ve duyguların şekillendirilerek belirli bir çerçeveye oturtulması ciddi sorunlar yaratmaktadır. Öyle ki duyguları, davranışları ve ifadeleri değiştirilen çalışan, duygularının işletme tarafından satın alınmaya çalışıldığını düşünmektedir. Bu durum ise, çalışanın herhangi bir özgürlük hissetmemesi, kendisini yalnız ve güçsüz hissetmesi sonucu işe yabancılaşmasına neden olmaktadır (Tokmak, 2014; Kaya ve Serçeoğlu, 2013). Ayrıca işletmeler açısından çalışanların gerçekte hissetmediği duyguları örgütsel gösterim kuralları doğrultusunda sergilemeleri her ne kadar örgütsel performansı arttırıcı bir unsur olarak görülse de bu durum çalışanlar açısından, işe yabancılaşma ile birlikte iş tatminsizliği, tükenmişlik, işten ayrılma niyeti ile stres ve psikolojik rahatsızlıklar gibi birçok olumsuz sonuçlara sebep olmaktadır (Grandey, 2000, Tokmak, 2014, Beğenirbaş, 2015). Gerek çalışanlar açısından bu olumsuz sonuçların ortadan kaldırılması gerekse de örgütsel performans açısından çalışanların hissetmiş oldukları duyguları örgütsel gösterim kuralları ile uyumlu hale getirerek sergilemeleri ise çalışanların psikolojik sermayelerinin artırılmasıyla mümkün olmaktadır. Bu noktadan hareketle duygusal emeğin bireylerin psikolojik durumları üzerindeki etkisi göz önüne alındığında, çalışanların psikolojik sermayelerin yüksek olmasl, duygusal emekten kaynaklanan duygusal emek kullanımının neden olacağı olumsuzluklara karşı olumlu katkılar sağlayacağı düşünülmektedir. 


\section{Teori ve Hipotezler}

\section{Duygusal Emek ve İşe yabancılaşma Arasındaki İlişki}

Duyguların ticarileştirilerek çalışma yaşamının bir parçası konumuna geldiğini belirten Hochschild $(1979,1983)$, tüm kuramcılar içinde özellikle Karl Marx ve Erving Goffman analizlerinden etkilenmiştir. Hochschild'in duygu kuramının temelinde Marx'ın, emeğin emekçileri yabancılaştıran bir meta olarak kullanımı üzerine geliştirdiği analiz ile Goffman'ın yüz yüze etkileşime getirdiği sosyolojik bakış yatmaktadır (Gassmann, 2010, s.10). Hochschild (1983), bu iki kuramcının çalışmalarını ve kendi araştırmasını kullanarak emeğin ne olduğu ve kim tarafından ortaya çıkarıldığı fikrine odaklanmaktadır.

Hochschild, duygusal emek teorisini geliştirirken duygu yönetimi perspektifinden faydalanmış ve duygusal emek kavramının "bir ücret karşılığında sarf edildiğini ve dolayısıyla değişim değerine sahip olduğunu" belirtmiş ve kavramı "dışarıdan gözlemlenebilecek yüz ve beden hareketlerini oluşturmak için duyguların yönetilmesi" manasında kullanmıştır (Hochschild, 1983, s.7). Goffman (1959)'un Toplumsal etkileşimlere ilişkin dramaturjik perspektifi benimseyen Hochschild çalışana aktör, müşteriye izleyici, iş yerine etkileşimin gerçekleştiği sahne dediği bir düzen kurmuştur. Hochschild'e göre duygusal emekçiler arasında görülen kişiler arası etkileşim, emek ilişkileri analizinde önemli bir yer teşkil etmektedir (Hochschild, 1983, s.33).

Hochschild (1983)'in, duygusal emek kuramını geliştirirken, duyguların temelinde yararlandığı bir diğer isim ise Karl Marx olmuştur. Hochschild (1983), Marx'ın emeğin emekçileri yabancılaştıran bir meta olarak kullanımı üzerine geliştirdiği analizden yararlanmıştır. Hochshild (1983)'in 19. yüzyıldaki çocuk işçilerin fiziksel sömürü koşullarıyla 20. yüzyılın hostes çalışanlarının duygusal sömürü koşulları arasında yaptığı karşılaştırmayı bu doğrultuda okumak mümkündür (Kaya ve Serçeoğlu, 2013). Duvar kağıdı fabrikasındaki işçi tarafından yapılan iş, zihin ve beden koordinasyonu şeklinde gerçekleşiyor ve süreç sadece fiziksel emek olarak adlandırılmaktaydı. Tıpkı duvar kağıdı fabrikasında çalışan işçi gibi hosteste, yiyecek-içecek servisi yapmak için kullandığı arabayı iterken fiziksel emek harcamakta, acil iniş ve tahliye hazırlığında ise 
zihinsel olarak çaba sarf etmektedir. Hochshild (1983), 19.yüzyıl şartlarında çalışma yaşamında duvar fabrikasında çalışan iş̧̧inin çalışırken sadece zihinsel ve fiziksel olarak çaba harcadığını, duygularını pek fazla çalışma yaşamına katamadığını, 20.yüzyılda ise hosteslerin çalışma yaşamında, çalışırken zihinsel ve fiziksel çabanın yanı sıra günümüz çalışma yaşamının önemli bir parçası olan duyguları da çalışma yaşamında kullandıklarını belirtmektedir (Brook, 2009).

Hochschild (1983)'in belirttiği üzere, hizmet sahnesinde çalışanın artık belirli duyguları sergilemek için kendi duygularından uzaklaşarak işinde iyi olmak için işletmenin ondan talep ettiği biçimde yüzeysel ya da derinlemesine davranışlar sergilemek durumundadır.

Yüzeysel davranışta çalışanlar rol yapma tekniğini kullanarak gerçekte hissetmiş oldukları duygulardan kopmadan gösterim kuralları çerçevesinde ifadelerini değiştirerek duygularını düzenlemektedirler (Asforth ve Humprey, 1993). Yüzeysel davranış, duyguların değiştirmeksizin, ifadelerinin değiştirilmesini kapsadığından, çalışanlar bir sahne sanatçısı gibi hissetmediği bir duyguyu sadece farklılaştırarak müşteriyi tatmin etmeye çabalamaktadırlar. Dolayısıyla, çalışanlar yüzeysel davranışta kendi duygularıyla değil gösterim kuralları doğrultusunda hareket etmektedirler. Çalışanın kendi duyguları çerçevesinde değil de sürekli olarak gösterim kuralları doğrultusunda hareket etmesi zorunluluğu ise duygusal çelişkiye yol açmaktadır. Çalışanın kendi duygu, düşünce ve değerleriyle işinin gerekleri arasında yaşadığı duygusal çelişki işini anlamlandıramamasına yol açmaktadır. Bu durum ise duygusal çelişkinin çalışanlarda iş tatmininin azalmasına (Ghalandari ve Jogh, 2012), tükenmişliğe (Martinez vd., 2007), işten ayrılma niyetine (Beğenirbaş ve Çalışkan, 2014) ve stres ve psikolojik rahatsızlıklara (Çelik ve Yıldız, 2016) yol aç九t̆ğ gözlemlenmiştir.

Derinlemesine davranış ise bir duygu ya da hissin seviye ya da niteliğini değiştirmeye çalışma eylemidir. Derinlemesine davranış yöntemiyle duygular aktif bir biçimde uyarılır, baskılanır ya da şekillendirilir (Hochschild, 1983). Derinlemesine davranış, çalışanların içsel duygularına odaklanılarak gösterim kuralları doğrultusunda örgütün sergilenmesini istediği duyguları gerçekten yaşamayı veya hissetmeyi denemesini gerektirmektedir. Çalışan hissetmiş olduğu duyguları gösterim kuralları ile uyumlu hale getirmek için kendisinde var olan veya tecrübe yoluyla 
edindiği duyguları sergilemesi gerekmektedir. Derinlemesine davranışta çalışan kendi duygularını kendisinden istenen uygun davranışlarla bütünleştirerek sergilediği zaman duygusal olarak çok fazla çaba harcamamaktadır. Ancak kendisinden istenen davranışlarla hissetmiş olduğu duygular örtüşmediği zaman çalışan uygun olan bu duyguyu sergileyebilmek adına daha fazla duygusal çaba harcamaktadır. Dolayısıyla, derinlemesine davranışta gösterim kuralları doğrultusunda istenen uygun davranışın sergilenebilmesi için yüzeysel davranışa göre daha fazla duygusal çaba harcanmaktadır (Ashforth ve Humphrey, 1993). Ayrıca çalışanlar uygun olan davranışları sergileyebilmek adına duygusal kaynak yaratmak için duyguların inşasında daha fazla stres yaşamaktadırlar. Yaşanan stres ise çalışanlarda psikolojik rahatsızlıklara neden olmakla birlikte, tükenmişliğe ve kendine yabancılaşmaya yol açmaktadır (Prentice, 2013).

Samimi davranış ise yüzeysel davranış ve derinlemesine davranıştan farklı olarak herhangi bir şekilde rol yapmayı gerektirmeyen doğal duygularla örtüssen bir davranış türüdür (Chu ve Murrmann, 2006). Hissedilen duyguların örgütün istemiş olduğu duygu gösterim kurallarıyla örtüştüğü samimi davranışta, hissettiklerini gizlemeye ihtiyaç duymayan çalışan kendi duygularıyla davranış sergilemektedir. Dolayısıyla, Dahling ve Perez (2010)'in de belirttiği üzere, samimi davranış örgütün amaçları doğrultusunda çalışanlardan istenen davranışlardır. İş yaşamında bireylerin karşılaşmış oldukları farklı durumlarda kendilerinden istenen çeşitli duygularla, gerçekte hissettikleri duygular örtüştügü zaman bireylerin rol yapmaya ihtiyacı kalmamaktadır. Örgütün istediği davranış kurallarıyla, çalışanın hissettiği duygular aynı doğrultuda olduğu zaman, çalışan yüzeysel ve derin davranış sergilemeyerek duygusal emeğin olumsuz sonuçlarından daha az etkilenecek ve işe yabancılaşma yaşamayacaktır (Beğenirbaş, 2015).

Dolayısıyla, duyguların işe yönelik algıları etkilemesinden dolayı, yüzeysel ve derinlemesine davranışta, gerek çalışanın kendi duygu, düşünce ve değerleriyle işinin gerekleri arasında yaşadığı duygusal çelişkinin işini anlamlandıramamasına yol açmasından gerekse de duygusal emeğin çalışanlarda yaratmış olduğu olumsuz etkilerden yola çıarak çalışanların gerek yüzeysel davranış gerekse de derinlemesine davranış sergileyerek duygularını sahteleştirmeleri çalışanların işlerine karşı olan 
algılarının değişmesine ve böylece işe yabancılaşmalarına neden olmaktadır (Beğenirbaş, 2015).

Duygusal emek ve onun alt boyutları ile işe yabancılaşma arasındaki ilişkiyi belirlemeye yönelik yapılan çalışmalara bakıldığında ise Beğenirbaş (2015), yapmış olduğu çalışmada yüzeysel davranışın işe yabancılaşmayı pozitif yönde anlamalı olarak etkilediği ve samimi davranış sergilemenin ise işe yabancılaşmayı negatif yönde anlamalı olarak etkilediği bulgusuna ulaşılmıştır. Yine benzer şekilde Çelik ve Atik (2016), tarafından yapılan çalışmada da yüzeysel davranış sergilemenin işe yabancılaşmayı pozitif yönde anlamalı olarak etkilediği bulgusu elde edilmiştir.

Duygusal emek ve işe yabancılaşma arasındaki ilişkiyi belirlemeye yönelik çalışmalara bakıldığında ise Kaya ve Serçeoğlu (2013) tarafından yapılan araştırmada duygusal emeğin (duygusal çelişki, duygusal çaba) işe yabancılaşmayı pozitif ve anlamalı olarak etkilediği tespit edilmiştir. Benzer şekilde, Tokmak (2014)'ün duygusal emek ve işe yabancılaşma arasındaki ilişkiyi belirlemeye yönelik yaptığı çalışmada da duygusal emeğin işe yabancılaşmayı pozitif ve anlamlı olarak etkilediği tespit edilmiştir.

Teorik açıklamalar ve araştırmalardan elde edilen bulgulara dayanılarak duygusal emek ve işe yabancılaşma arasındaki ilişkiye yönelik aşağıdaki hipotez ortaya konulmuştur.

- H1.Duygusal emek, İşe yabancılaşmayı pozitif yönde anlamlı olarak etkilemektedir

- Hıa: Yüzeysel davranış, işe yabancılaşmayı pozitif yönde anlamlı olarak etkilemektedir.

- Hıb: Derinden davranış, işe yabancılaşmayı pozitif yönde anlamlı olarak etkilemektedir.

- Hı: Samimi davranış, işe yabancılaşmayı negatif yönde anlamlı olarak etkilemektedir.

\section{Duygusal Emek ve Psikolojik Sermaye Arasındaki İlişki}

Tamer (2015) ve Hur vd. (2016)'ya göre, psikolojik sermaye çalışanların yüzeysel davranış sergilemektense derinlemesine davranış sergileme ile çalışanların olumlu duyguları sergilemeye teşvik edecek güce sahiptir. 
Hur vd. (2016)'ya göre, psikolojik sermaye ile çalışanlar gerekli çaba ve kaynakları iş gereksinimlerini yerine getirmek için gerekli motivasyona ve psikolojik kapasiteye sahip olacaktır. Olumlu pozitif kaynaklar ve bilişsel esneklik çalışanların bilişlerini ve duygusal durumlarını rahatlıkla değiştirebilir. Bu olumlu etki sayesinde ise çalışanlar, yüzeysel davranış sergilemektense derinlemesine davranış sergileyebilirler. Ayrıca, olumlu esnek düşünme ve proaktif psikolojik kapasiteler, çalışanların iş normlarını ve değerlerini içselleştirerek yüzeysel davranış sergilemektense kendi hissetmiş oldukları duygular aracılığıyla müşterilerle etkileşime girebilirler.

Psikolojik sermayenin bileşenleri açısından duygusal emek ile olan ilişkisine bakıldığında ise psikolojik sermaye genel anlamda iki neden dolayı çalışanların yüzeysel davranış sergilemektense derinlemesine davranış sergileme kapasitelerini geliştirebilir (Hur vd., 2016). Birincisi, yüksek düzeyde umuda ve öz yeterliliğe sahip bireyler amaca giden yolda karşılaştıkları engelleri aşmak için gerekli yeteneğe, kararlılığa ve motivasyona sahiptirler (Snyder, 2000). Umut, olumlu duyguları körükleyen ve insanlarda refah duygusunu körüklemekte büyük rol oynamaktadır. Snyder vd. (1991), umut ile kaygı arasında negatif bir ilişki olduğunu belirtmişlerdir. Bu açıdan, umut düzeyi yüksek olan bireyler fiziksel ve zihinsel açıdan birçok sorunla başa çıabilecek güce sahiptirler (Norman vd., 2005). Bireyin belirli yetenekleri üretmek için kişinin bilişsel kaynakları harekete geçirmesi ve eylemleri organize etmesi için gerekli olan inanç (Bandura,1997) yani öz yeterlilik sayesinde yüksek düzeyde öz yeterliliğe sahip bireyler, zorluklar karşısında azimli ve sabırlı davranarak, güçlüklerle başa çıkabilmek için gerekli olan inanca ve güce sahiptirler (Luthans vd., 2007a). Dolayısıyla, yüksek düzeyde umut ve öz yeterliliğe sahip olan çalışanlarda bulunan gerekli motivasyon ve güçten dolay1 çalışanlar, yüzeysel davranış sergilemektense kendi duygularını içselleştirerek derinlemesine davranış sergileyecek ve böylece duygusal emeğin olumsuz çıtılarından etkilenmeyeceklerdir (Tamer, 2015; Hur vd., 2016). İkincisi ise iyimserlik ve dayanıklılık sayesinde çalışanların çevreye karşı olan olumlu bakış açılarıdır. İyimserlik, bireyin geçmişte, şu anda veya gelecekte yaşamış olduğu veya yaşaması olası olumlu ve olumsuz olayların nedenini anlamaya yönelik bir durumdur (Luthans vd., 2007a,s.87). İyimserliğe sahip olan bireyler, ümit edilen hedeflerin 
gerçekleştirilmesi için olumlu olayları kişisel, göreli olarak değişmez ve genel nedenlere, olumsuz olayları ise dişsal, değişken ve durumsal faktörlere bağladıkları için zorluklar karşısında olumsuz olarak etkilenmekten kaçınırlar (Seligman,1998, 2002, 2007). Bireyin herhangi önemli bir zorluk veya belirli risk ile karşılaşması durumunda içinde bulunduğu duruma göstereceği pozitif uyum durumunda yani dayanıklılık (Masten ve Reed, 2002) sayesinde ise bireyler, terslik, çatışma, belirsizlik, başarısızlık ve hatta pozitif değişim ve ilerleme gibi olumlu durumlar karşısında kendilerini toparlayabilme kapasitesine sahiptirler (Luthans, 2002 ve Luthans vd., 2007a). Dolayısıyla, yüksek düzeyde iyimserlik ve dayanıklılığa sahip bireyler mesleklerine ve çevreye karşı olumlu bir bakış açısına sahiptirler ve iş ile ilgili karşılaştıkları güçlükleri sadece zorlayıcı bir unsur olarak algıladıkları için, yüzeysel davranış sergilemektense kendi duygularını içselleştirerek derinlemesine davranış sergileyecek ve böylece duygusal emeğin olumsuz çıtılarından etkilenmeyeceklerdir (Hur vd., 2016).

Psikolojik sermayenin çalışanlarda yaratmış olduğu olumlu etki, psikolojik sermayenin bileşenlerinin (umut, öz yeterlilik, iyimserlik ve dayanıklılık) birlikte çalışmasının yaratmış olduğu sinerji etkisidir. Psikolojik sermaye bileşenlerinin birlikte çalışması etkisi, bileşenlerin ayrı ayrı çalışması etkisinden büyük bulunmuştur (Luthans vd., 2007b). Dolayısıyla, çalışanların psikolojik sermayelerinin geliştirilerek duygusal emeğin olumsuz çıktılarının azaltılabilmesi için çalışanlarda psikolojik sermayenin bir bütün olarak geliştirilmesi gerekmektedir.

Duygusal emek ve psikolojik sermaye arasındaki ilişkiyi belirlemeye yönelik araştırmalara bakıldığında ise Beğenirbaş (2015)'ın, yaptığı araştırmada, psikolojik sermayenin, dayanıklılık bileşeni hariç diğer tüm bileşenlerinin (umut, öz yeterlilik, iyimserlik) ve genel anlamda psikolojik sermayenin, yüzeysel davranışı negatif yönde anlamlı olarak etkilediği ve psikolojik sermayenin tüm bileşenleri (umut, öz yeterlilik, iyimserlik ve dayanıklılık) ve genel anlamda psikolojik sermayenin samimi davranışı pozitif yönde anlamlı olarak etkilediği bulgularına ulaşılmıştır.

Duygusal emek ve psikolojik sermaye arasındaki ilişkiyi belirlemeye yönelik Tamer (2015) tarafından işletme çalışanları ve yöneticilerine yönelik yapılan çalışmada ise, psikolojik sermayenin umut bileşenin derinlemesine davranışı pozitif yönde anlamlı olarak etkilediği, psikolojik 
sermayenin dayanıklılık ve öz yeterlilik bileşenlerinin ise yüzeysel davranışı negatif yönde anlamlı olarak etkilediği, ayrıca öz yeterlilik bileşeninin ise samimi davranışı pozitif yönde anlamlı olarak etkilediği bulgularına ulaşılmıştır.

Hur vd. (2016), tarafından Güney Kore'de uçuş görevlileri ile yapılan çalışmada ise psikolojik sermayenin tüm bileşenleri (umut, öz yeterlilik, iyimserlik ve dayanıklılık) ile derinlemesine davranış arasında pozitif yönde anlamlı bir ilişki olduğu sonucuna ulaşılmıştır.

Teorik açıklamalar ve araştırmalardan elde edilen bulgulara dayanılarak duygusal emek ve psikolojik sermaye arasındaki ilişkiye yönelik aşağıdaki hipotez ortaya konulmuştur.

- H2.Duygusal emek, psikolojik sermayeyi negatif yönde anlamlı olarak etkilemektedir.

- $\mathrm{H}_{2 a}$ : Yüzeysel davranış, iyimserliği negatif yönde anlamlı olarak etkilemektedir.

- H2b: Yüzeysel davranış, umut'u negatif yönde anlamlı olarak etkilemektedir.

- H2c: Yüzeysel davranış, öz yeterliliği negatif yönde anlamlı olarak etkilemektedir.

- H2d: Yüzeysel davranış, dayanıklılığı negatif yönde anlamlı olarak etkilemektedir.

- $\mathrm{H}_{2 \mathrm{e}}$ : Derinden davranış, iyimserliği negatif yönde anlamlı olarak etkilemektedir.

- $\mathrm{H}_{2 f:}$ Derinden davranış, umut'u negatif yönde anlamlı olarak etkilemektedir.

- $\mathrm{H}_{2 g}$ : Derinden davranış, öz yeterliliği negatif yönde anlamlı olarak etkilemektedir.

- $\quad H_{2 h}$ : Derinden davranış, dayanıklılığı negatif yönde anlamlı olarak etkilemektedir.

- $\mathrm{H}_{21}$ : Samimi davranış, iyimserliği pozitif yönde anlamlı olarak etkilemektedir.

- $\mathrm{H}_{2 i}$ : Samimi davranış, umut'u pozitif yönde anlamlı olarak etkilemektedir.

- $\quad \mathrm{H}_{2 j}$ : Samimi davranış, öz yeterliliği pozitif yönde anlamlı olarak etkilemektedir. 
- $\mathrm{H}_{2 k}$ : Samimi davranış, dayanıklılığı pozitif yönde anlamlı olarak etkilemektedir.

\section{Psikolojik Sermaye ve İşe Yabancılaşma Arasındaki İlişki}

İşe yabancılaşmaya neden olabilecek olumsuz durumların ortadan kaldırılması ve çalışanların olumuz özelliklerinin olumlu hale getirilmesi ve mevcut olumlu özelliklerinin de geliştirilerek çalışma yaşamında çalışanların işe yabancılaşmasının önüne geçebilme çalışanların psikolojik sermayelerinin yükseltilmesine bağlıdır. Beğenirbaş (2015)'e göre, psikolojik sermayeleri yani sorumluluk alma konusunda öz yeterlilikleri yüksek, güçlüklerle başa çıkma konusunda dayanıklılık göstererek amaçları başarıyla elde etmede umutlu ve iyimser çalışanların iş ortamlarına gerçekte hissetmiş oldukları duygularını yansıtarak işe yabancılaşma sorunundan da uzaklaşabileceklerdir. Tokmak (2014)'e göre ise, işletmelerde çalışanların güçlü yönlerinin ve psikolojik kapasitelerinin durağan olmadığı ve geliştirilebilir olmasından hareketle çalışanların performanslarının artırılması için psikolojik sermaye bileşenlerinin (öz yeterlilik, umut, iyimserlik ve dayanıklılık) geliştirilmesinin çalışanların işlerinde daha fazla çaba harcamalarına ve işlerine bağlanmasına olanak sağlayacağı bu durumun ise işe yabancılaşmayı azaltacağı değerlendirilmektedir.

Psikolojik sermaye ve iş yabancllaşma arasındaki ilişkiyi belirlemeye yönelik yapılan çalışmalara bakıldığında ise Tokmak (2014)'ın, yapmış olduğu çalışmada, çalışanların sahip oldukları psikolojik sermayelerinin duygusal emek ile işe yabancılaşma arasındaki ilişkide düzenleyici bir rol üstlendiği sonucuna ulaşılmıştır. Beğenirbaş (2015)'1n, psikolojik sermayenin, duygu gösterimleri ve işe yabancilaşma etkileri üzerine sağlık sektöründe yaptığı araştırmada işe psikolojik sermayenin psikolojik dayanıklılık alt boyutu hariç diğer tüm alt boyutları ve genel anlamda psikolojik sermayenin işe yabanclaşmayı negatif ve anlamlı olarak etkilediği sonucuna ulaşılmıştır.

Teorik açıklamalar ve araştırmalardan elde edilen bulgulara dayanılarak duygusal emek ve psikolojik sermaye arasındaki ilişkiye yönelik aşağıdaki hipotez ortaya konulmuştur. 
- H3.Psikolojik sermaye, İşe yabancılaşmayı negatif yönde anlamlı olarak etkilemektedir.

- Hзa: İyimserlik, işe yabancılaşmayı negatif yönde anlamlı olarak etkilemektedir.

- H3b: Umut, işe yabancılaşmayı negatif yönde anlamlı olarak etkilemektedir.

- $\mathrm{H}_{3 c}$ : Öz yeterlilik, işe yabancılaşmayı negatif yönde anlamlı olarak etkilemektedir.

- H3a: Dayanıklılık, işe yabancılaşmayı negatif yönde anlamlı olarak etkilemektedir.

Çalışanların gerçekte hissetmediği duyguları örgütsel gösterim kuralları doğrultusunda sergilemeleri her ne kadar örgütsel performansı arttırsa da çalışanlar açısından, işe yabancılaşmaya sebep olmaktadır. Gerek çalışanlar açısından bu olumsuz sonucun ortadan kaldırılması gerekse de örgütsel performans açısından çalışanların hissetmiş oldukları duyguları örgütsel gösterim kuralları ile uyumlu hale getirerek sergilemeleri ise çalışanların psikolojik sermayelerinin artırılmasıyla mümkün olacaktır. Bu doğrultuda çalışmanın ana amacına yönelik olarak aşağıdaki hipotez ortaya konulmuştur.

- H4.Duygusal emek ile işe yabancılaşma arasındaki ilişkide psikolojik sermayenin düzenleyici etkisi vardır.

\section{Yöntem}

Yapılan araştırma kapsamında, ana değişkenler arasındaki ilişkileri ortaya çıkarmak amacı ile Şekil 1'de gösterilen bir model oluşturulmuştur. Araştırmada ayrıca alt boyutlar arasındaki ilişkileri ortaya çıkarmak amacı ile Şekil 2' de gösterilen bir model oluşturulmuştur.

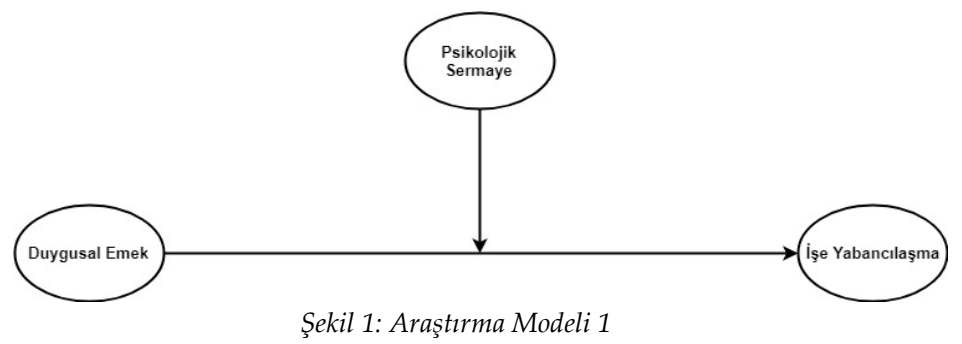




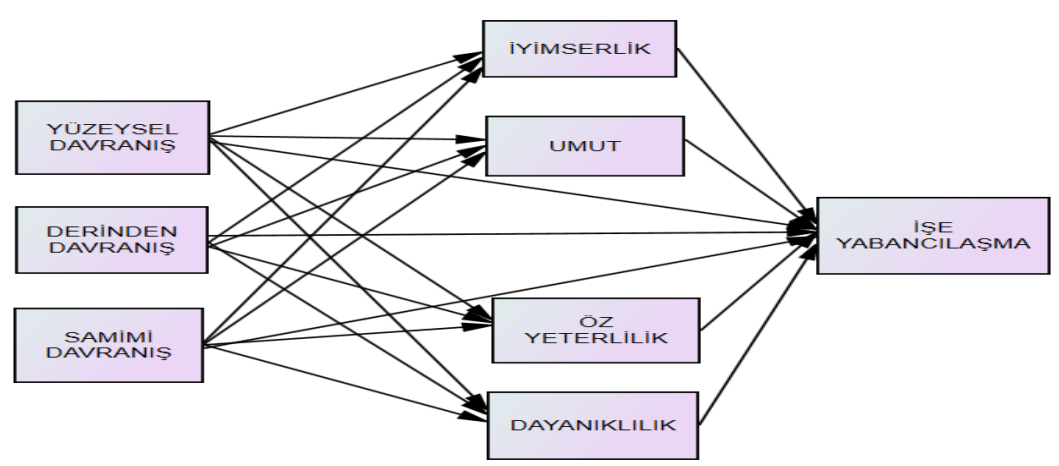

Şekil 2: Araştırma Modeli 2

\section{Araştırmanın Evreni ve Örneklemi}

Bu araştırmanın evrenini Gaziantep, Adana ve Osmaniye illerindeki 4 ve 5 yıldızlı otellerde çalışan yaklaşık 3200 kişi oluşturmaktadır. Araştırmanın örneklemini ise evreni temsil edecek nitelikte, farklı otellerden rastlantısal olarak seçilen katılımcılar oluşturmaktadır. Araştırmada, otel çalışanlarından anket aracılığı ile toplanan veriler kullanılmıştır. 650 adet anket katılımcılara uygulanmış, 50 adet anket cevaplandırılmamış, 51 anket ise eksik cevaplandırılmıştır. Analizi yapılan gözlem sayısı 549'dur. Katılımcıların 117'si kadın 432 ise erkeklerden oluşturmaktadır. Katılımcıların 207'si 18-30 yaş aralığında, 222 'si 31-40 yaş aralığında, 120 'si ise 41 ve üzeri yaşa sahiptir. Katılımcıların 72'si orta ve alt düzey yönetici pozisyonunda, 477'si ise işçilerden oluşmaktadır. Katılımcıların 211'i ön büro, 38'i satış-pazarlama, 280'1 yiyecek-içecek, 8'i halkla ilişkiler ve 22' side insan kaynakları departmanında çalışmaktadır.

\section{Araştırmanın Ölçekleri}

Duygusal Emek Ölçeği Katılımcıların duygusal emek algılarının ölçülmesinde Diefendorff vd. (2005) tarafından geliştirilen ve Türkçe uyarlaması Basım ve Beğenirbaş (2012) tarafından yapılan ölçek kullanılmıştır. Ölçek; yüzeysel davranış sergileme (6 ifade), derinlemesine davranış sergileme (4 ifade) ve samimi davranışlar ( 3 ifade) olmak üzere üç ayrı boyuttan ve 
toplam 13 ifadeden oluşmaktadır. Diefendorff vd. (2005) araştırmasında ölçeğin güvenirlik katsayısını yüzeysel davranış boyutu için $\alpha=0,92$, derinlemesine davranış boyutu için $\alpha=0,85$ ve samimi davranış boyutu için ise $\alpha=0,83$ olarak bildirmiştir. Basım ve Beğenirbaş (2012) ise, araştırmasında ölçeğin güvenirlik katsayısını birinci örneklemde; yüzeysel davranış boyutu için $\alpha=0,83$, derinlemesine davranış boyutu için $\alpha=0,87$ ve samimi davranış boyutu için $\alpha=0,80$ ve ikinci örneklemde ise yüzeysel davranış boyutu için $\alpha=0,84$, derinlemesine davranış boyutu için $\alpha=0,86$ ve samimi davranış boyutu için $\alpha=0,86$ olarak bildirmiştir.

Ölçeğe yönelik yapılan KFA sonucunda ölçeğin üç faktörlü yapısına uyum sağladığ1 ve 13 maddelik ölçeğin faktör yüklerinin 0,80 ile 0,93 aralığında olduğu tespit edilmiştir. Yüzeysel davranış boyutunun faktör yüklerinin 0,81 ile 84 arasında, derinlemesine davranış davranış boyutunun faktör yüklerinin 0,80 ile 0,85 arasında ve samimi davranış boyutunun faktör yüklerinin 0,88 ile 0,93 arasında olduğu tespit edilmiştir. Ölçeğin KMO analiz sonucu 0,748 ve Barlett testi anlamlı $(\mathrm{p}=.000)$ olarak tespit edilmiştir. Bu analizlerin ardından AMOS paket programı ile doğrulayıcı faktör analizi yapılmıştır. Faktör analizi sonucunda verilerin ölçeğin üç faktörlü yapısına uyum sağladığı ve yüzeysel davranış boyutunun faktör yükleri 0,79 ile 0,84; derinlemesine davranış boyutunun faktör yüklerinin 0,63 ile 0,96 ve samimi davranış sergileme boyutunun faktör yüklerinin ise 0,83 ile 0,97 aralığında değer aldığ görülmüştür. Yapılan güvenirlik analizi sonucunda ölçeğin Cronbach alfa güvenirlik katsayısı; yüzeysel davranış için $\alpha=0.81$, derinlemesine davranış için $\alpha=0.88$ ve samimi davranış boyutu için $\alpha=0.74$, entelektüel uyarım için $\alpha=0.80$ ve ilham verici motivasyon için ise $\alpha=0.91$ olarak bulunmuştur.

Psikolojik Sermaye Ölçeği: Katılımcıların psikolojik sermaye düzeylerinin ölçülmesinde Luthans vd. (2007c) tarafından geliştirilen ve Türkçe uyarlaması Çetin ve Basım (2012) tarafından yapılan ölçek (PCQ-24) kullanılmıştır. Ölçek; iyimserlik (6 ifade), psikolojik dayanıklılık (6 ifade), umut (6 ifade) ve öz yeterlilik (6 ifade) olmak üzere dört ayrı boyuttan ve toplam 24 ifadeden oluşmaktadır. Luthans vd.(2007c), araştırmasında ölçeğin güvenirlik katsayısını; umut boyutu için $\alpha=0,88$, psikolojik da- 
yanıklılık boyutu için $\alpha=0,89$, öz yeterlilik boyutu için $\alpha=0,89$ ve iyimserlik boyutu için $\alpha=0,89$ olarak bildirmiştir. Çetin ve Basım (2012) ise araştırmasında ölçeğin güvenirlik katsayısını; umut boyutu için $\alpha=0,81$, psikolojik dayanıklılık boyutu için $\alpha=0,68$, öz yeterlilik boyutu için $\alpha=$ 0,85 ve iyimserlik boyutu için $\alpha=0,67$ olarak bildirmiştir.

Ölçeğe yönelik yapılan KFA sonucunda ölçeğin üç faktörlü yapısına uyum sağladığ1 ve 20 maddelik ölçeğin faktör yüklerinin 0,78 ile 0,93 aralığında olduğu tespit edilmiştir. Keşfedici faktör analizi neticesinde faktör yükü düşük çıan ve iki faktöre birden yüklenen iyimserlik faktörüne ait S14 ve S24; umut faktörüne ait S15 ve dayanıklılık faktörüne ait S21 numaralı maddeler çıkarılmıştır. Bu maddeler çıkarıldıktan sonra ölçeğin 20 maddelik ölçek yapısı için hesaplanan KMO (KaiserMeyer-Olkin) testi sonunda KMO değeri 0,847 olarak tespit edilmiş olup faktör analizi için örneklem büyüklügü yeterlidir. İyimserlik boyutunun faktör yüklerinin 0, 901 ile 0,94 arasında, umut boyutunun faktör yüklerinin 0,88 ile 0,92 arasında, öz yeterlilik boyutunun faktör yüklerinin 0,91 ile 0,93 arasında ve dayanıklılık boyutunun faktör yüklerinin 0,78 ile 0,82 arasında olduğu tespit edilmiştir. Bu analizlerin ardından AMOS paket programı ile doğrulayıcı faktör analizi yapılmıştır. Faktör analizi sonucunda verilerin ölçeğin dört faktörlü yapısına uyum sağladığı ve iyimserlik boyutunun faktör yüklerinin 0,86 ile 0,96 aralığında; öz yeterlilik boyutunun faktör yüklerinin 0,94 ile 0,95 aralığında; dayanılılık boyutunun faktör yüklerinin 0,87 ile 0,92 aralığında ve umut boyutunun faktör yüklerinin ise 0,88 ile 0,95 aralığında değerler aldığ 1 bulgusu elde edilmiştir. Yapılan güvenirlik analizi sonucunda ölçeğin Cronbach alfa güvenirlik katsayısı; iyimserlik boyutu için $\alpha=0.95$, umut boyutu için $\alpha$ $=0.96$, öz yeterlilik boyutu için $\alpha=0.97$ ve dayanıklılık boyutu için ise $\alpha$ $=0.95$ olarak bulunmuştur.

İşe Yabancılaşma Ölçeği: İşe yabancılaşmanın ölçülmesinde Hirschfeld ve Field (2000), tarafından geliştirilen ve Türkçe uyarlaması Özbek (2011), tarafından yapılan ölçek kullanılmıştır. Ölçek 10 ifadeden oluşmaktadır. Hirschfeld ve Field (2000) araştırmasında ölçeğin güvenirlik katsayısını 0,80 olarak bildirmiştir. Özbek (2011) ise araştırmasında ölçeğin güvenirlik katsayısını 0,71 olarak bildirmiştir. 
Ölçeğe yönelik yapılan KFA sonucunda faktör yükü düşük çıan S38 numaralı madde analizden çıkarılmıştır. $\mathrm{Bu}$ madde analizden çıkartıldıktan sonra ölçeğin 9 maddelik yapısı için hesaplanan KMO (Kaiser-Meyer-Olkin) testi sonunda KMO değeri 0.935 olarak tespit edilmiş olup faktör analizi için örneklem büyüklüğü yeterlidir. Faktör yüklerinin ise .766 ile .873 aralığında olduğu tespit edilmiştir. Bu analizlerin ardından AMOS paket programı ile doğrulayıcı faktör analizi yapılmıştır. Faktör analizi sonucunda verilerin ölçeğin tek faktörlü yapısına uyum sağladığ 1 ve faktör yüklerinin 0,71 ile 0,87 arasında olduğu tespit edilmiştir. Yapılan güvenirlik analizi sonucunda ölçeğin cronbach alfa güvenirlik katsayısı 0.94 olarak bulunmuştur.

Tablo 1: Ölçeklerin Uyum İyiliği Değerleri

\begin{tabular}{|c|c|c|c|c|c|c|c|c|}
\hline Değişken & $X^{2}$ & df & $\begin{array}{l}\text { CMIN/ } \\
\text { DF }\end{array}$ & GFI & AGFI & CFI & TLI & $\begin{array}{r}\text { RMS } \\
\text { EA }\end{array}$ \\
\hline Duygusal Emek & 181.554 & 50 & 3.631 & .956 & .92 & .978 & .965 & 0.069 \\
\hline $\begin{array}{l}\text { Psikolojik } \\
\text { Sermaye }\end{array}$ & 497.403 & 135 & 3.684 & .917 & .871 & .98 & .971 & 0.07 \\
\hline İşe yabancılaşma & 41.025 & 14 & 2.93 & .984 & .948 & .994 & .984 & 0.059 \\
\hline
\end{tabular}

DFA sonucu ölçeklerin uyum iyiliği değerlerini sağladığı görülmektedir. DFA sonucu ölçeklerin kabul edilebilir uyum iyiliği değerlerini sağladığı görülmektedir. Ki kare/ sd bütün değişkenler için 5'in altında değer almıştır. RMSEA da bütün değişkenler için 0,08'in altında değer almıştır. CFI, GFI, AGFI ve TLI da iyi uyum değerlerini sağlamıştır.

\section{Bulgular}

Değişkenlerin tanımlayıcı istatistiklerine ilişkin bilgiler Tablo 2'de verilmiştir. Tablo 2'de görüldüğğ gibi basıklık ve çarpıklık değerleri -2 ile +2 arasında dağılmaktadır. Bu sonuç bize verilerin normal dağıldığı bulgusunu vermektedir. 
Tablo 2. Değişkenler Tanımlayıcı İstatistik Bilgileri

\begin{tabular}{lccccccc}
\hline & Min & Max & Toplam & $\begin{array}{c}\text { Ortalam } \\
\mathbf{a}\end{array}$ & $\begin{array}{c}\text { Std. } \\
\text { Sapma }\end{array}$ & $\begin{array}{c}\text { Çarpık } \\
\text { lik }\end{array}$ & $\begin{array}{c}\text { Basık } \\
\text { lik }\end{array}$ \\
\hline Yüzeysel Davranış & 1.00 & 5.00 & 1585.50 & 2.8880 & 1.18175 & .061 & -1.294 \\
\hline $\begin{array}{l}\text { Derinlemesine } \\
\text { Davranış }\end{array}$ & 1.00 & 5.00 & 2052.50 & 3.7386 & 1.00420 & -.979 & .257 \\
\hline Samimi Davranış & 1.00 & 5.33 & 1703.67 & 3.1032 & 1.03853 & .148 & -.717 \\
\hline Duygusal Emek & 1.00 & 5.00 & 1756.46 & 3.1994 & .61614 & -.178 & .797 \\
\hline İyimserlik & 1.00 & 6.00 & 1496.00 & 2.7250 & 1.79134 & .462 & -1.401 \\
\hline Umut & 1.00 & 6.00 & 2282.40 & 4.1574 & 1.83927 & -.523 & -1.268 \\
\hline Öz yeterlilik & 1.00 & 6.00 & 2271.83 & 4.1381 & 1.83267 & -.521 & -1.259 \\
\hline Dayanıklılık & 1.20 & 6.00 & 2625.60 & 4.7825 & 1.46855 & -.911 & -.656 \\
\hline Psikolojik Sermaye & 1.65 & 5.90 & 2207.75 & 4.0214 & 1.12710 & -.374 & -.915 \\
\hline İşe Yabancilaşma & 1.00 & 5.00 & 1751.78 & 3.1909 & 1.26794 & -.286 & -1.505 \\
\hline
\end{tabular}

Değişkenlere ait verilen ortalama cevaplarına bakıldığında çalışanların umut, öz yeterlilik, dayanıklılık, psikolojik sermaye düzeylerinin yüksek; derinlemesine davranış, işe yabancılaşma, samimi davranış ve duygusal emek düzeylerinin orta; yüzeysel davranış ve iyimserlik düzeylerinin ise düşük olduğu görülmüştür.

Araştırmada daha sonra değişkenler arasındaki ilişkinin tespit edilmesi amacıyla korelasyon analizi yapılmıştır.

Tablo 3. Korelasyon Tablosu

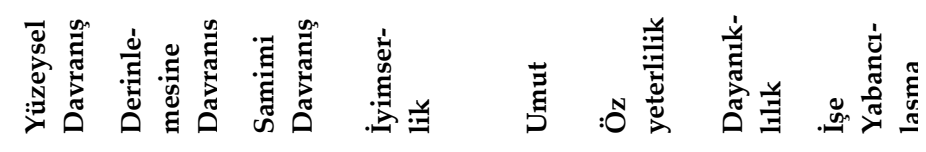

\begin{tabular}{|c|c|c|c|c|c|c|c|c|}
\hline $\begin{array}{l}\text { Yüzeysel } \\
\text { Davranıs }\end{array}$ & (.919) & & & & & & & \\
\hline $\begin{array}{l}\text { Derinlemesine } \\
\text { Davranıș }\end{array}$ & .061 & $(.885)$ & & & & & & \\
\hline $\begin{array}{l}\text { Samimi } \\
\text { Davranış }\end{array}$ &,$- 352^{* *}$ & .005 & $(.913)$ & & & & & \\
\hline İyimserlik &,$- 220^{* *}$ & -.026 & ,131 & $(.957)$ & & & & \\
\hline Umut & -.079 & -.076 & , 288* & 197" & $(.969)$ & & & \\
\hline Öz yeterlilik & $-110^{* *+}$ & $-131^{* *}$ & (140"** & 198** & .057 & $(.978)$ & & \\
\hline Dayanıklılık & $-130^{* * *}$ &,$- 243^{* * *}$ & ,341** & $-170^{* *}$ &, $510^{* * *}$ & ,481** & $(.954)$ & \\
\hline $\begin{array}{l}\text { Işe } \\
\text { Yabancılaşma }\end{array}$ & (279"* & ,225" &,$- 338^{* *}$ &,$- 367^{\prime \prime \prime}$ &,$- 289^{* * *}$ &,$- 312^{* *}$ &,$- 322^{* * *}$ & $(.949)$ \\
\hline
\end{tabular}

${ }^{* *} 0,01$ anlamllık düzeyinde anlamlı 
Korelasyon analizi neticesinde yüzeysel davranış ile işe yabancılaşma arasında pozitif yönde anlamlı bir ilişki, yüzeysel davranış ile samimi davranış, iyimserlik, öz yeterlilik ve dayanıklılık arasında negatif yönde düşük düzeyde anlamlı bir ilişki olduğu, derinlemesine davranış ile işe yabancılaşma arasında pozitif yönde anlamlı ve öz yeterlilik ve dayanıklılık ile negatif yönde bir ilişki olduğu, samimi davranış ile işe yabanclışma arasında negatif yönde anlamlı bir ilişki ve samimi davranış ile iyimserlik, umut, dayanıklılık ve öz yeterlilik ile pozitif yönde anlamlı bir ilişki olduğu, iyimserlik ile umut ve öz yeterlilik arasında pozitif yönde anlamlı bir ilişki ve iyimserlik ile dayanıklılık ve işe yabancılaşma arasında negatif yönde anlamlı bir ilişki olduğu, umut ile dayanıklılık arasında pozitif yönde anlamlı ve işe yabancılaşma ile ise negatif yönde anlamlı yönde bir ilişki olduğu, öz yeterlilik ile dayanıklılık arasında pozitif yönde anlamlı ve işe yabancılaşma ile negatif yönde anlamlı bir ilişki olduğu ve dayanıklılık ile işe yabancılaşma arasında negatif yönde anlamlı bir ilişki olduğu görülmüştür.

Araştırmanın bundan sonraki aşamasında ise yapısal eşitlik modeli kurulmuştur. Yapısal eşitlik modeli Şekil 3' te, uyum iyiliği değerleri Tablo $4^{\prime}$ te ve regresyon ağırlıkları Tablo 5 'te verilmiştir.

Tablo 4. Yapısal Model Uyum İyiliği Değerleri

\begin{tabular}{lcccccccc}
\hline & $\mathbf{X}^{\mathbf{2}}$ & $\mathbf{d f}$ & $\begin{array}{l}\text { CMIN/ } \\
\text { DF }\end{array}$ & GFI & AGFI & CFI & TLI & RMSEA \\
\hline $\begin{array}{l}\text { Yapisal } \\
\text { Model }\end{array}$ & 1965.309 & 768 & 2.559 & .851 & .825 & .958 & .953 & 0.053 \\
\hline
\end{tabular}

Tablo 4'te görüleceği üzere yapısal eşitlik modeli Kabul edilebilir uyum iyiliği değerlerini sağlamaktadır ve model iyi uyum göstermektedir (Yıldız ve Çetindaş 2018). CMIN/DF nin 5' in altında olması, rmsea nın 0,08 in altında olması CFI ve TLI nın 0,95'in üzerinde olması bize bu bulguyu vermektedir. 


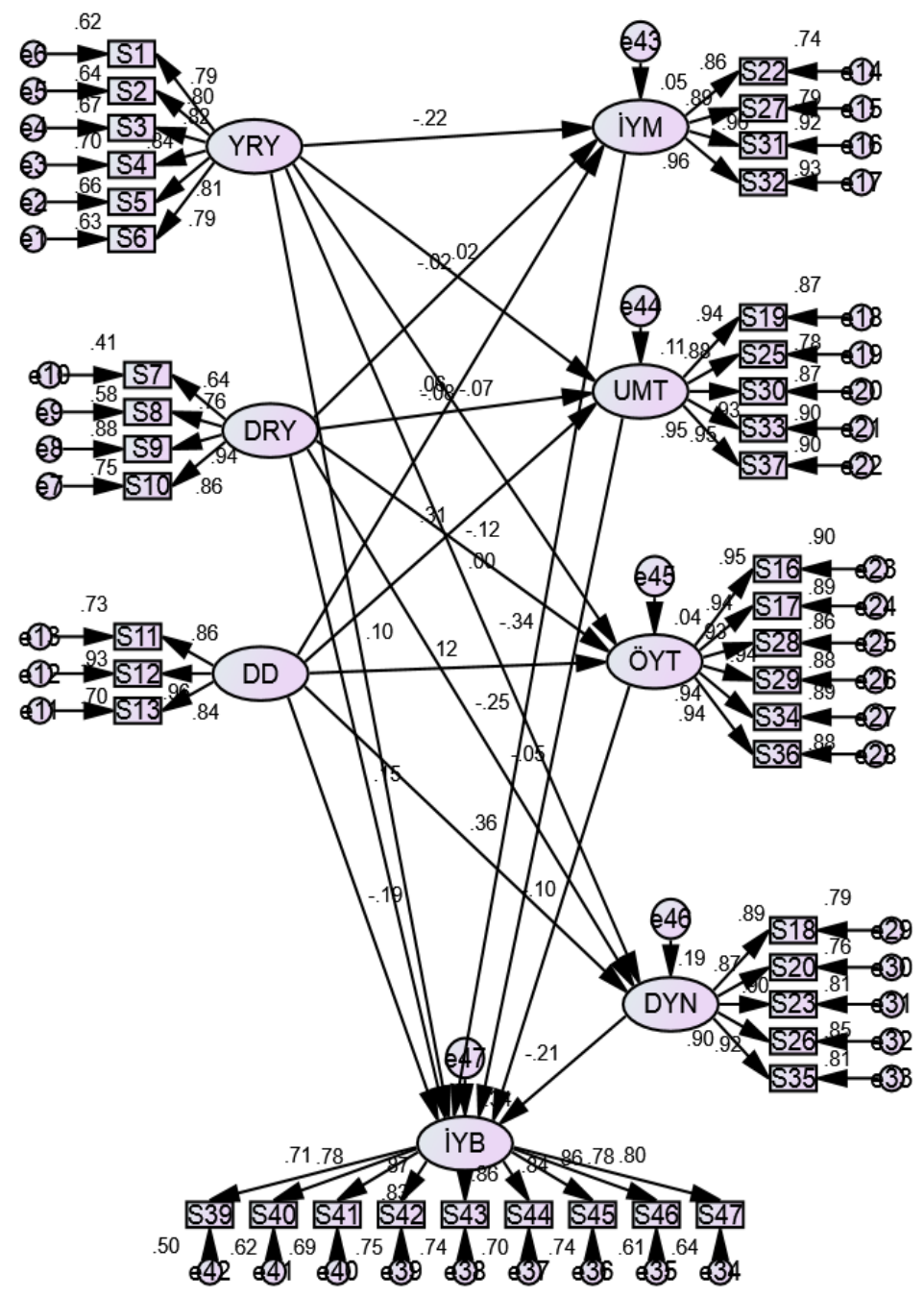

Şekil 3. Yapısal Eşitlik Modeli 1 
Tablo 5. Yapısal Eşitlik Modeli 1 Regresyon Ă̆ırlıkları

\begin{tabular}{|c|c|c|c|c|c|c|}
\hline Test Edilen Yol & & & Tahmin & Std.Hata & Kritik Oran & Anlamlılık \\
\hline İyimserlik & $<--$ & $\begin{array}{l}\text { Yüzeysel } \\
\text { Davranış }\end{array}$ & -0.33 & 0.074 & -4.493 & $* * *$ \\
\hline Umut & $<--$ & $\begin{array}{l}\text { Yüzeysel } \\
\text { Davranış }\end{array}$ & 0.05 & 0.078 & 0.646 & 0.519 \\
\hline Öz Yeterlilik & $<--$ & $\begin{array}{l}\text { Yüzeysel } \\
\text { Davranış }\end{array}$ & -0.111 & 0.078 & -1.416 & 0.157 \\
\hline Dayanıklılık & $<--$ & $\begin{array}{l}\text { Yüzeysel } \\
\text { Davranış }\end{array}$ & 0.013 & 0.056 & 0.227 & 0.82 \\
\hline İyimserlik & $<---$ & $\begin{array}{l}\text { Derinleme- } \\
\text { sine } \\
\text { Davranış }\end{array}$ & -0.037 & 0.069 & -0.534 & 0.593 \\
\hline Umut & $<--$ & $\begin{array}{l}\text { Derinleme- } \\
\text { sine } \\
\text { Davranış }\end{array}$ & -0.142 & 0.074 & -1.922 & 0.055 \\
\hline Öz Yeterlilik & $<--$ & $\begin{array}{l}\text { Derinleme- } \\
\text { sine } \\
\text { Davranış }\end{array}$ & -0.209 & 0.075 & -2.775 & 0.006 \\
\hline Dayanıklılık & $<--$ & $\begin{array}{l}\text { Derinleme- } \\
\text { sine Davranış }\end{array}$ & -0.326 & 0.055 & -5.97 & $* * *$ \\
\hline İyimserlik & $<--$ & $\begin{array}{l}\text { Samimi } \\
\text { Davranış }\end{array}$ & 0.085 & 0.077 & 1.104 & 0.27 \\
\hline Umut & $<--$ & $\begin{array}{l}\text { Samimi } \\
\text { Davranış }\end{array}$ & 0.579 & 0.085 & 6.785 & $* * *$ \\
\hline Öz Yeterlilik & $<--$ & $\begin{array}{l}\text { Samimi } \\
\text { Davranış }\end{array}$ & 0.218 & 0.085 & 2.575 & 0.01 \\
\hline Dayanıklılık & $<--$ & $\begin{array}{l}\text { Samimi } \\
\text { Davranı̧̧ }\end{array}$ & 0.498 & 0.063 & 7.924 & $* * *$ \\
\hline $\begin{array}{l}\text { İşe } \\
\text { Yabancılaşma }\end{array}$ & $<---$ & $\begin{array}{l}\text { Yüzeysel } \\
\text { Davranış }\end{array}$ & 0.101 & 0.047 & 2.161 & 0.031 \\
\hline $\begin{array}{l}\text { İşe } \\
\text { Yabancılaşma }\end{array}$ & $<--$ & $\begin{array}{l}\text { Derinleme- } \\
\text { sine Davranış }\end{array}$ & 0.173 & 0.046 & 3.775 & $* * *$ \\
\hline $\begin{array}{l}\text { İşe } \\
\text { Yabancılaşma }\end{array}$ & $<--$ & $\begin{array}{l}\text { Samimi } \\
\text { Davranış }\end{array}$ & -0.223 & 0.054 & -4.133 & $* * *$ \\
\hline $\begin{array}{l}\text { İşe } \\
\text { Yabancılaşma }\end{array}$ & $<--$ & İyimserlik & -0.25 & 0.036 & -7.02 & $* * *$ \\
\hline $\begin{array}{l}\text { İşe } \\
\text { Yabancılaşma }\end{array}$ & $<--$ & Umut & -0.035 & 0.033 & -1.043 & 0.297 \\
\hline $\begin{array}{l}\text { İşe } \\
\text { Yabancılaşma }\end{array}$ & $<--$ & Öz Yeterlilik & -0.064 & 0.033 & -1.967 & 0.049 \\
\hline $\begin{array}{l}\text { İşe } \\
\text { Yabancılaşma }\end{array}$ & $<--$ & Dayanıklılık & -0.181 & 0.057 & -3.177 & 0.001 \\
\hline
\end{tabular}

Tablo 5'te görüldüğü gibi yapısal eşitlik modelinin analizi neticesinde yüzeysel davranış sergilemenin iyimserliği negatif yönde anlamlı olarak etkilediği tespit edilmiştir. Bu bulgu yüzeysel davranış sergileme düzeyi arttı̆̆ında iyimserliğin azaldığını göstermektedir. Katsayı tahmin değeri - 
0,33 olarak elde edilmiştir. Bu bulgu yüzeysel davranışın $1 \mathrm{br}$. artması sonucu iyimserliğin 0,33 br azaldığını göstermektedir. Derinlemesine davranış sergilemenin öz yeterliliği ve dayanıklılı̆̆ı negatif yönde anlamlı olarak etkilediği bulunmuştur. Bu bulgu derinlemesine davranış düzeyinin artması neticesinde öz yeterlilik ve dayanıklılık seviyelerinin azalmakta olduğunu göstermektedir. Derinlemesine davranış 1 br artış gösterdiğinde öz yeterlilik 0,209 br ve dayanıklılık 0,326 br. azalmaktadır. Samimi davranış sergilemenin umut, öz yeterlilik ve dayanıklılı̆̆ pozitif yönde anlamlı olarak etkilediği tespit edilmiştir. Bu bulgu samimi davranış sergilemenin 1 br artması durumunda 0,085 br, öz yeterliliğin 0,085 br ve dayanıklılığın 0,063 br artış göstereceğini vermektedir. Yüzeysel davranış ve derinlemesine davranış sergilemenin işe yabancılaşmayı pozitif yönde anlamlı olarak etkilediği tespit edilmiştir. Yani yüzeysel ve derinlemesine davranış sergileme düzeyi artış gösterdiğinde işe yabancılaşmada da artış meydana gelmektedir. Yüzeysel davranış 1 br arttı̆̆ında işe yabancılaşma 0,047 br artmakta ve derinlemesine davranış 1 br arttığında işe yabacılaşma 0,046 br artmaktadır. Samimi davranış sergileme, iyimserlik, öz yeterlilik ve dayanıklılı̆̆ın işe yabancılaşmayı negatif yönde anlamlı olarak etkilediği bulguları elde edilmiştir. Bu bulgu samimi davranış sergileme seviyesinin artması, iyimserlik düzeyinin artması öz yeterlilik ve dayanıklılı̆̆ın artması durumunda işe yabancılaşmanın azalacağını göstermektedir. Bu sonuçlara göre H1a, H1b, H1c, H2a, H2g, H2h, H2i, H2j, H2k, H3a, H4c, H3d hipotezleri kabul edilmiştir.

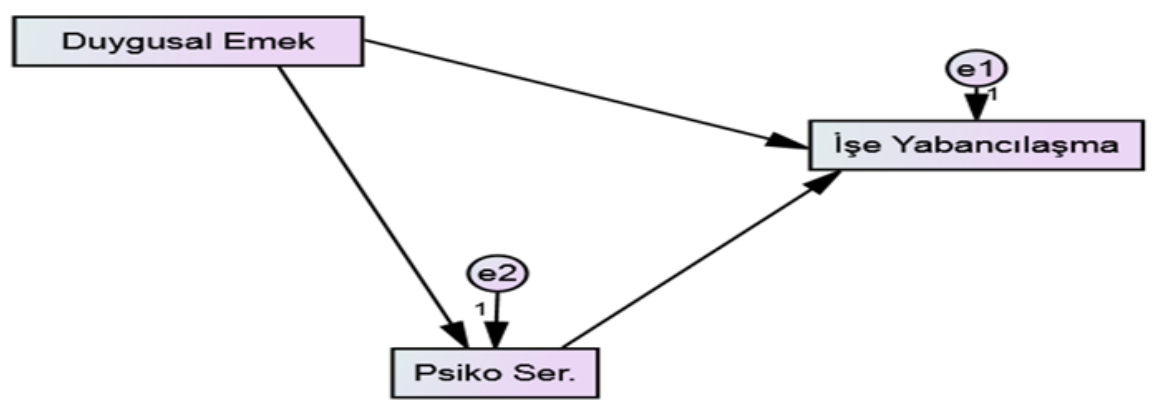

Şekil 4.Yapısal Eşitlik Modeli 2 
Ana değişkenler ile ilgili hipotezleri test etmek amaciyla amos programında analiz yapılmış, analiz şekli Şekil 4'te ve regresyon ağırlıkları Tablo 6' da verilmiştir.

Tablo 6. Yapısal Eşitlik Modeli 2 Regresyon Ağırlıklan

\begin{tabular}{|c|c|c|c|c|c|c|}
\hline \multicolumn{3}{|l|}{ Test Edilen Yol } & \multirow{2}{*}{$\begin{array}{l}\text { Tahmin } \\
-0.036\end{array}$} & \multirow{2}{*}{$\begin{array}{l}\text { Std.Hata } \\
0.052\end{array}$} & \multirow{2}{*}{$\begin{array}{l}\begin{array}{l}\text { Kritik } \\
\text { Oran }\end{array} \\
-0.685\end{array}$} & \multirow{2}{*}{$\begin{array}{l}\text { Anlamlılık } \\
0.044\end{array}$} \\
\hline $\begin{array}{l}\text { Psikolojik } \\
\text { Sermaye }\end{array}$ & $<<--$ & $\begin{array}{l}\text { Duygusal } \\
\text { emek }\end{array}$ & & & & \\
\hline $\begin{array}{l}\text { İşe } \\
\text { Yabancılaşma }\end{array}$ & $<--$ & $\begin{array}{l}\text { Duygusal } \\
\text { emek }\end{array}$ & 0.223 & 0.089 & 2.516 & 0.012 \\
\hline $\begin{array}{l}\text { İşe } \\
\text { Yabancılaşma }\end{array}$ & $<--$ & $\begin{array}{l}\text { Psikolojik } \\
\text { Sermaye }\end{array}$ & -0.989 & 0.072 & -13.743 & $* * *$ \\
\hline
\end{tabular}

Tablo 6'da görüldüğg̈ gibi duygusal emek psikolojik sermayeyi negatif yönde anlamlı olarak etkilemektedir. Bu bulgu duygusal emek düzeyinin artması neticesinde psikolojik sermaye düzeyinde azalış meydana geleceğini göstermektedir. Duygusal emek 1 br arttığında psikolojik sermaye 0,036 br azalmaktadır. Duygusal emek işe yabancılaşmayı ise pozitif yönde anlamlı olarak etkilemektedir. Bu bulgu duygusal emek gösterme düzeyindeki artışı işe yabancılaşmayı da artırdığını göstermektedir. Duygusal emek 1 br arttığında işe yabancılaşma $0,223 \mathrm{br}$ artmaktadır. Çalışanlar ne kadar çok duygusal emek gösterirlerse o kadar çok işe yabancılaşmaktadır. Psikolojik sermaye ise işe yabancılaşmayı negatif yönde anlamlı olarak etkilemektedir. Bu bulgu psikolojik sermayedeki artışın işe yabancılaşmayı azalttığı anlamlına gelmektedir. Psikolojik sermaye 1 br artış gösterdiğinde işe yabancılaşma 0,989 br azalmaktadır. Katsayı tahmin değeri 1'e çok yakındır. Bu bulgu işe yabancilaşma üzerinde psikolojik sermayenin önemli bir rolü olduğunu göstermektedir. Bu sonuçlara göre $\mathrm{H1}, \mathrm{H} 2$ ve $\mathrm{H} 3$ hipotezleri kabul edilmiştir.

Düzenleyici etki yapısal modeli Şekil 5'te, modifikasyonlar sonucu elde edilen modelin uyum iyiliği değerleri Tablo 7'de ve modelin regresyon ağırlıkları Tablo 8' de verilmiştir. 


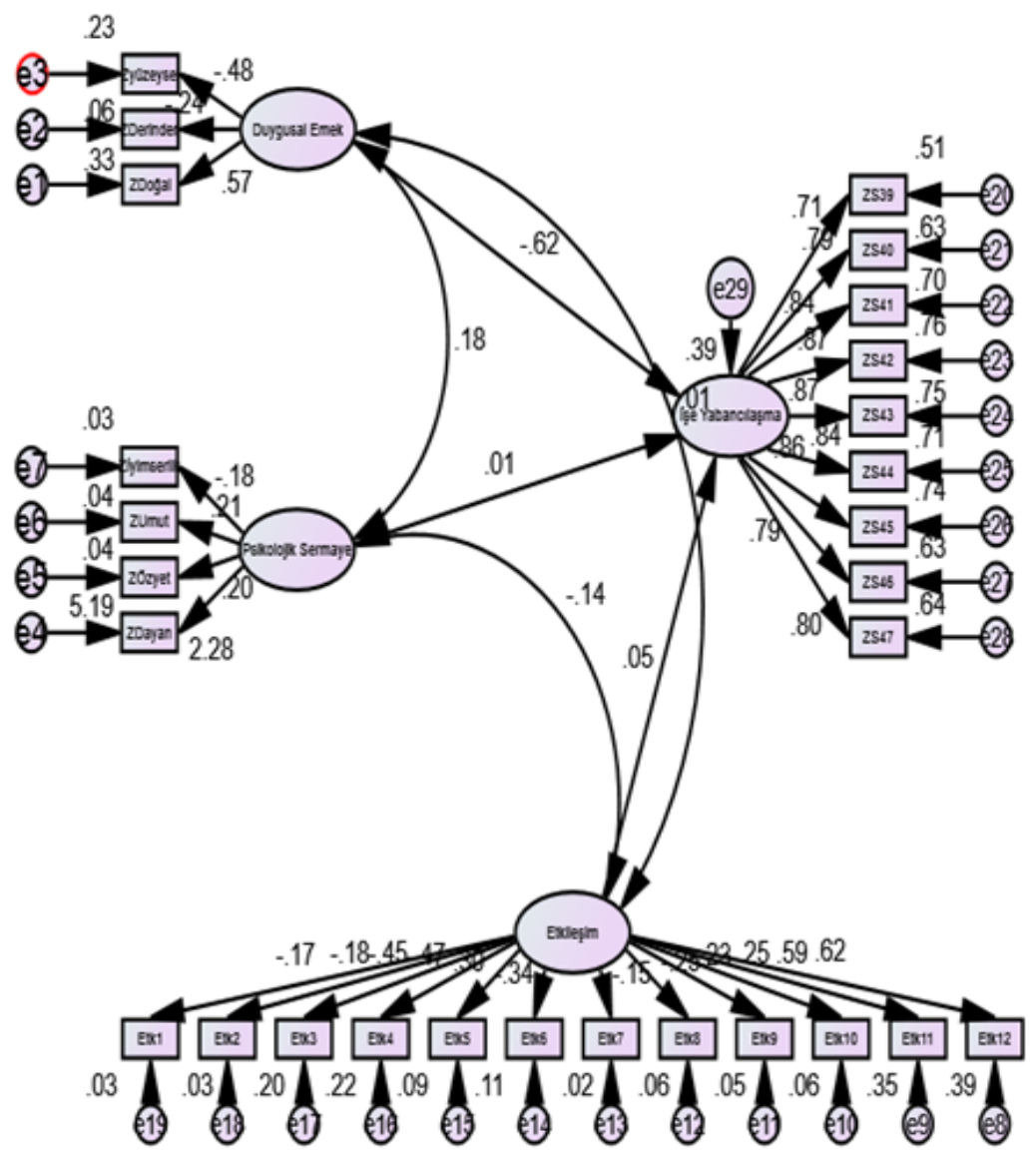

Şekil 5. Düzenleyici Etki Yapısal Model 1

Tablo 7. Düzenleyici Etki Model 1 Uyum İyiliği Değerleri

\begin{tabular}{lllllllll}
\hline & $\mathrm{X}^{2}$ & $\mathrm{df}$ & \multicolumn{1}{c}{ CMIN/ } & GFI & AGFI & CFI & TLI & RMSEA \\
\hline $\begin{array}{l}\text { Düzen- } \\
\text { leyici }\end{array}$ & 1267.409 & 308 & 4.115 & 0.864 & 0.821 & 0.901 & 0.878 & 0.075 \\
Model & & & & & & & & \\
\hline
\end{tabular}

Model Kabul edilebilir uyum iyiliği değerlerini sağlamaktadır. Bu bulguyu CMIN/DF nin 5'in altında bulunması, RMSEA nın 0,08 in altında elde edilmesi ve CFI nın 0,90 in üzerinde değer alması göstermektedir. 
Tablo 8. Düzenleyici Etki Regresyon Ăğırlıkları 1

\begin{tabular}{|c|c|c|c|c|c|c|}
\hline Test Edilen Yol & & & Tahmin & Std.Hata & $\begin{array}{l}\text { Kritik } \\
\text { Oran }\end{array}$ & Anlamlilık \\
\hline İşe Yabancilaşma & $\leftarrow-$ & $\begin{array}{l}\text { Duygusal } \\
\text { Emek }\end{array}$ & -0.579 & 0.106 & -5.473 & $* * *$ \\
\hline İşe Yabancilaşma & $\leftarrow-$ & $\begin{array}{l}\text { Psikolojik } \\
\text { Sermaye }\end{array}$ & -0.002 & 0.001 & -2.698 & 0.007 \\
\hline İşe Yabancılaşma & $\leftarrow$ & Etkileşim & -2.995 & 2.007 & 0.845 & 0.398 \\
\hline
\end{tabular}

Tablo 8 'de görüldüğü gibi duygusal emek ve psikolojik sermaye işe yabancılaşmayı anlamlı olarak etkilemekte fakat etkileşim değişkeni işe yabancılaşmayı anlamlı olarak etkilememektedir. Bu nedenle duygusal emeğin işe yabancılaşma üzerindeki etkisinde psikolojik sermayenin düzenleyici rolü bulunmamaktadır. Çünkü duygusal emek ile psikolojik sermayenin çarpımından oluşan etkileşim değişkeni işe yabancılaşmayı anlamlı olarak etkilememiştir. Bu bulgudan sonar duygusal emeğin alt boyutları bağımsız değişken olarak alınarak düzenleyici etki analizi yapılmıştır. Amos programında kurulan model Şekil 6'da ve model tahmin sonuçları ise Tablo 9'da verilmiştir.

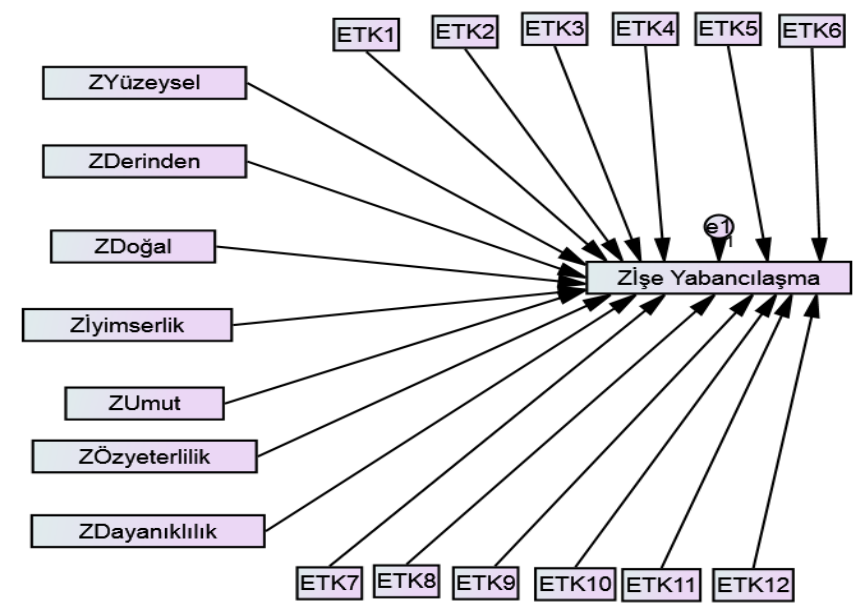

Şekil 6. Düzenleyici Etki Model 2 
Tablo 9. Düzenleyici Etki Model 2 Regresyon Ă̆ırlıkları

\begin{tabular}{|c|c|c|c|c|c|c|}
\hline Test Edilen Yol & & & Tahmin & Std.Hata & Kritik Oran & $\mathrm{P}$ \\
\hline İşe Yabancilaşma & $\leftarrow-$ & $\begin{array}{l}\text { Yüzeysel } \\
\text { Davranış }\end{array}$ & 0.466 & 0.129 & 3.628 & $* * *$ \\
\hline İşe Yabancilaşma & $\leftarrow-$ & $\begin{array}{l}\text { Derinlemesine } \\
\text { Davranış }\end{array}$ & 0.175 & 0.041 & 4.305 & $* * *$ \\
\hline İşe Yabancılaşma & $\leftarrow-$ & $\begin{array}{l}\text { Samimi } \\
\text { Davranış }\end{array}$ & -0.116 & 0.043 & -2.686 & 0.007 \\
\hline İşe Yabancılaşma & $\leftarrow$ & İyimserlik & -0.353 & 0.044 & -8.044 & $* * *$ \\
\hline İşe Yabancılaşma & $\leftarrow-$ & Umut & -0.038 & 0.047 & -0.809 & 0.419 \\
\hline İşe Yabancılaşma & $\leftarrow-$ & Öz yeterlilik & -0.094 & 0.048 & -1.95 & 0.051 \\
\hline İşe Yabancılaşma & $\leftarrow$ & Dayanıklılık & -0.238 & 0.063 & -3.802 & $* * *$ \\
\hline İşe Yabancılaşma & $\leftarrow$ & Etkileşim 7 & -0.082 & 0.058 & -1.42 & 0.156 \\
\hline İşe Yabancılaşma & $\leftarrow-$ & Etkileşim8 & 0.052 & 0.065 & 0.792 & 0.428 \\
\hline İşe Yabancılaşma & $\leftarrow$ & Etkileşim 9 & 0.031 & 0.057 & 0.556 & 0.578 \\
\hline İşe Yabancılaşma & $\leftarrow-$ & Etkileşim 10 & 0.009 & 0.059 & 0.153 & 0.878 \\
\hline İşe Yabancılaşma & $\leftarrow$ & Etkileşim 11 & 0.009 & 0.057 & 0.154 & 0.878 \\
\hline İşe Yabancılaşma & $\leftarrow-$ & Etkileşim 12 & -0.032 & 0.065 & -0.492 & 0.623 \\
\hline İşe Yabancilaşma & $\leftarrow-$ & Etkileşim 1 & 0.052 & 0.045 & 1.139 & 0.255 \\
\hline İşe Yabancılaşma & $\leftarrow$ & Etkileşim 2 & -0.09 & 0.029 & -3.081 & 0.002 \\
\hline İşe Yabancılaşma & $\leftarrow-$ & Etkileşim 3 & 0.021 & 0.049 & 0.433 & 0.665 \\
\hline İşe Yabancilaşma & $\leftarrow-$ & Etkileşim 4 & 0.132 & 0.059 & 2.254 & 0.024 \\
\hline İşe Yabancılaşma & $\leftarrow$ & Etkileşim 5 & 0.064 & 0.05 & 1.265 & 0.206 \\
\hline İşe Yabancılaşma & $\leftarrow$ & Etkileşim 6 & -0.012 & 0.052 & -0.23 & 0.818 \\
\hline
\end{tabular}

Tablo 9'da görüleceği gibi, yüzeysel davranış işe yabancılaşmayı pozitif yönde anlamlı olarak etkilemekte, dayanıklılık işe yabancılaşmayı negatif yönde anlamlı olarak etkilemekte ve yüzeysel davranış ile dayanıklılık değişkenlerinin çarpım değerlerinden oluşan etkileşim 4 değişkeni de işe yabancılaşmayı anlamlı olarak etkilemektedir. Bu sonuç bize yüzeysel davranış sergilemenin işe yabancılaşma üzerindeki etkisinde dayanıklılığın düzenleyici etkisi olduğunu göstermektedir.

Alt modellerle ilgili yapılan bu analizden sonra ana değişkenler üzerinden de hiyerarşik regresyon analizi yapılmış; kurulan model Şekil 7'de, modelin uyum iyiliği değerleri Tablo $10^{\prime}$ da ve tahmin sonuçları ise Tablo 11 'de verilmiştir.

Tablo 10.Düzenleyici Etki Model 3 Uyum İyiliği Değerleri

\begin{tabular}{lllllllll}
\hline & $\mathbf{X}^{2}$ & $\mathbf{d f}$ & $\begin{array}{l}\text { CMIN/ } \\
\text { DF }\end{array}$ & GFI & AGFI & CFI & TLI & RMSEA \\
\hline $\begin{array}{l}\text { Düzenley- } \\
\text { ici Model 3 }\end{array}$ & 4.53 & 3 & 1.51 & 0.996 & 0.987 & 0.991 & 0.982 & 0.03 \\
\hline
\end{tabular}




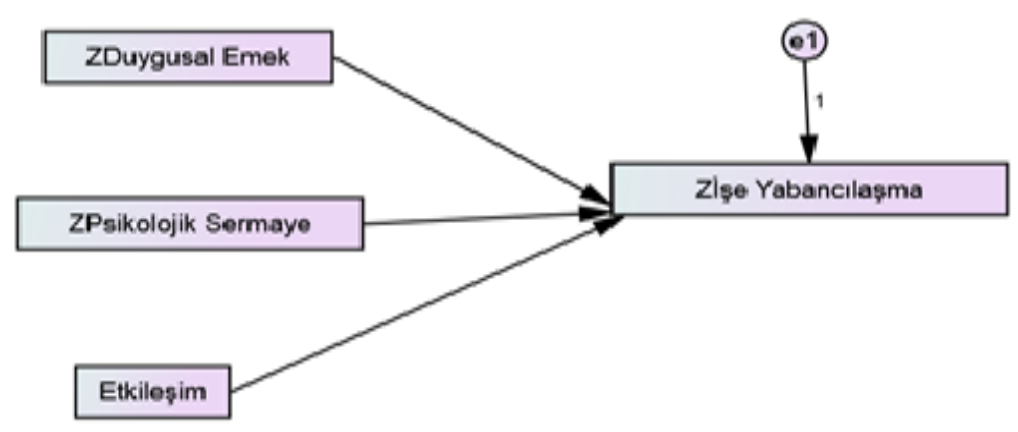

Şekil 7. Düzenleyici Etki Model 3

Tablo 11. Düzenleyici Etki 3 Regresyon Ağırlıkları

\begin{tabular}{lllllll}
\hline Test Edilen Yol & & & Tahmin & $\begin{array}{l}\text { Std. } \\
\text { Hata }\end{array}$ & $\begin{array}{l}\text { Kritik } \\
\text { Oran }\end{array}$ & P \\
\hline İşe Yabancılaşma & $<---$ & Duygusal Emek & 0.174 & 0.07 & 2.481 & 0.013 \\
İşe Yabancilaşma & $<---$ & Psikolojik Sermaye & -0.793 & 0.057 & -13.896 & $* * *$ \\
İşe Yabancılaşma & $<---$ & Etkileşim & 0.235 & 0.125 & 1.888 & 0.049 \\
\hline
\end{tabular}

Tablo 11'de görüldügü gibi duygusal emek işe yabancılaşmayı anlamlı olarak etkilemekte, psikolojik sermaye işe yabancılaşmayı anlamlı olarak etkilemekte, duygusal emek ile psikolojik sermayenin değerlerinin çarpımından elde edilen etkileşim değişkeni de işe yabancılaşmayı anlamlı olarak etkilemektedir. Bu sonuç bize duygusal emeğin işe yabancilaşma üzerindeki etkisinde psikolojik sermayenin düzenleyici etkisi olduğunu göstermektedir ve $\mathrm{H} 4$ hipotezi kabul edilmiştir.

Psikolojik sermayenin farklı düzeyleri (yüksek veya düşük olması) için, duygusal emek ile işe yabancılaşma arasındaki ilişkinin nasıl bir değişim gösterdiğini görmek için Şekil 7'de verilen, duygusal emek işe yabancılaşma ilişkisinde psikolojik sermayenin düzenleyici etkisini incelemek yerinde olacaktır. Buna göre psikolojik sermayenin düşük ve yüksek seviyelerinde sıfırdan farklı değerler elde edilmiştir. Psikolojik sermayenin seviyelerine göre duygusal emek ile işe yabancılaşma arasındaki ilişkinin aynı yönde devam etmesine karşılık, psikolojik sermayenin yüksek seviyede olması durumunda bu ilişkinin zayıfladığını ifade etmek mümkündür. 


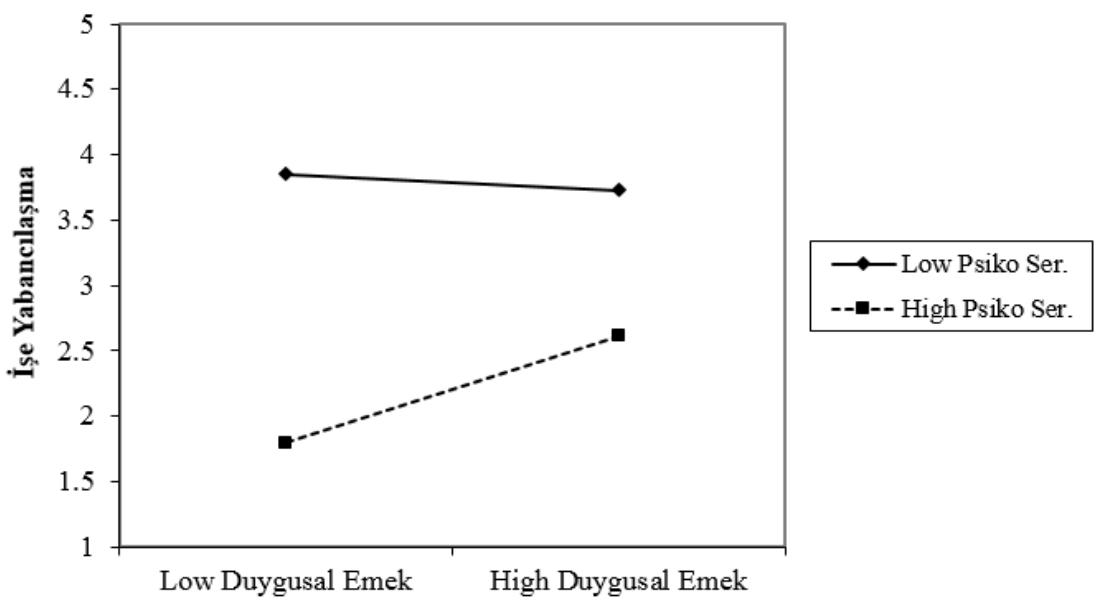

Şekil 8. Duygusal Emek İşe Yabancılaşma İlişkisinde Psikolojik Sermayenin Düzenleyici Etkisi

Şekil 8'de görüleceği gibi psikolojik sermaye artış gösterirken duygusal emek de artış göstermektedir. Yüksek psikolojik sermaye durumunda yüksek işe yabanclaşma gerçekleşmektedir. Düşük psikolojik sermaye durumunda da işe yabancılaşmada düşüş olmaktadır.

\section{Sonuç ve Öneriler}

Bu çalışmanın amacı, yoğun rekabet ortamında önemi her geçen gün artan duygusal emeğin çalışanların işe yabancılaşmasını etkileyen bir değişken olup olmadığını belirlemek ve çalışanların sahip oldukları psikolojik sermaye düzeylerinin duygusal emek ile işe yabancılaşma ilişkisinde düzenleyici bir etkisinin bulunup bulunmadığını araştırmaktır.

Araştırmada, duygusal emek ve bileşenleri ile işe yabancılaşma değişkenleri arasındaki ilişki kapsamında, yüzeysel davranış ve derinlemesine davranış sergilemenin işe yabancılaşmayı olumlu yönde anlamlı olarak etkilediği, samimi davranışın ise işe yabancılaşmayı olumsuz yönde etkilediği tespit edilmiştir. Bu sonuç, Beğenirbaş (2015) ve Çelik ve Atik (2016) tarafından yapılan çalışmalarının sonuçları ile uyumludur. Araştırmada genel olarak duygusal emeğin işe yabancılaşmayı olumlu yönde anlamlı olarak etkilediği tespit edilmiştir. Bu sonuç, Kaya ve 
Serçeoğlu (2013) ve Tokmak (2014) tarafından yapılan çalışmalarının sonuçları ile uyumludur. Duyguların çalışma yaşamında kullanılmasıyla birlikte, Hochschild (1983) duygusal emeği, hizmetin sahne, çalışanların aktör, müşterilerin de izleyici olarak nitelendirildiği bir oyun olarak ifade etmiştir. Çalışan artık işinde iyi olmak için işletmenin ondan talep ettiği biçimde yüzeysel ya da derinlemesine davranışlar sergilemek durumundadır (Hochschild,1983; Ashforth ve Humphrey, 1993, Grandey, 2000). Dolayısıyla, çalışan artık kendi duygularıyla değil, işletmenin gösterim kuralları çerçevesinde kendisinden istenen duygularla hareket etmek zorundadır. Çalışanın kendi duyguları çerçevesinde değil de sürekli olarak gösterim kuralları doğrultusunda hareket etmesi zorunluluğu duygusal çelişkiye yol açmaktadır. Çalışanın kendi duygu, düşünce ve değerleriyle işinin gerekleri arasında yaşadığı duygusal çelişki ise işini anlamlandıramamasına yol açmakta ve çalışan kendisine ve işine karşı yabancılaşma yaşamaktadır.

Duygusal emek bileşenleri ve psikolojik sermaye bileşenleri arasındaki ilişkiden elde edilen bulgulara göre; yüzeysel davranışın, iyimserliği olumsuz yönde etkilediği; derinlemesine davranışın, öz yeterliliği ve dayanıklılığı olumsuz yönde etkilediği; samimi davranış sergilemenin ise umut, öz yeterlilik ve dayanıklılığı olumlu yönde anlamlı olarak etkilediği belirlenmiştir. Bu sonuçlar, Beğenirbaş (2015) ve Tamer (2015)'in yapmış olduğu çalışmalar ile uyumludur. Yüksek düzeyde umut, öz yeterlilik, iyimserlik ve dayanıklılığa sahip çalışanlar, amaca giden yolda karşılaştıkları engelleri aşmak için gerekli yeteneğe, kararlılığa, motivasyona ve zorluklarla baş edebilecek dayanıklılığa sahip bireylerdir (Snyder,2000 ve Luthans vd., 2007a). Dolayısıyla, Tamer (2015) ve Hur vd. (2016)'nın da belirttiği üzere umut, öz yeterlilik, iyimserlik ve dayanıklılık düzeyi yüksek olan çalışanlar, fiziksel ve zihinsel açıdan birçok sorunla başa çıabilecek güce sahip oluklarından ve herhangi bir güçlük karşısında bilişsel kaynakları harekete geçirmek için eylemleri organize edebilme becerisine sahip olmalarının çalışanlara kazandırmış olduğu motivasyon ve güçten dolayı, çalışanların hissetmedikleri duyguları yüzeysel davranış yoluyla sergilemektense, umut, öz yeterlilik, iyimserlik ve dayanıklılık sayesinde elde etmiş oldukları kazanımlar yoluyla derinlemesine davranış sergileyerek, duygusal emeğin olumsuz çıktılarından etkilenmeyecekleri değerlendirilmesi yapılabilir. 
Çalışmanın ana amacına yönelik yapılan analizler sonucunda ise psikolojik sermayenin duygusal emek ile işe yabancılaşma arasındaki ilişkide düzenleyici bir rol üstlendiği bulgusu elde edilmiştir. Bu sonuç, Tokmak (2014)'ın yapmış olduğu çalışma ile uyumludur. Bu sonuca yönelik, çalışanların hissetmiş oldukları duygular ile değil de gösterim kuralları çerçevesinde hissetmedikleri duyguları sergileyerek yaşamış oldukları duygusal uyumsuzluğun sonucu işe yabancılaşmalarını önlemek için çalışanların psikolojik sermayelerinin geliştirilmesi duygusal emekten kaynaklanan işe yabancılaşma sorununu azaltacağı değerlendirilmesi yapılabilir.

Psikolojik sermayenin gerek bileşenlerinin (umut, öz yeterlilik, iyimserlik ve dayanıklılık) her biri tek başına, gerekse de bu bileşenlerin toplamı olan psikolojik sermayenin kendisinin insan kaynaklarının geliştirilmesi ve performansın artması ile birlikte işletmelere rekabet avantajı sağladığı görülmektedir (Luthans vd., 2010). Dolayısıyla işletmelerin gerek duygusal emekten kaynaklanan işe yabancılaşma sorunun önüne geçilmesi gerekse de müşteri tatminin arttırılması konusunda çalışanların psikolojik sermayelerinin arttırılmasına yönelik çalışmalar yapması olumlu sonuçlar alınmasına neden olacağı değerlendirilmesi yapilabilir.

Araştırma sonuçları çerçevesinde uygulayıcılara ve araştırmacılara yönelik bazı öneriler ise şu şekildedir;

- Mevcut çalışanların psikolojik sermayelerinin geliştirilmesi, örgütsel, ekonomik ve sosyo-psikolojik motivasyon araçlarryla güdülenmesi, çalışma koşullarının iyileştirilmesi, çalışanlara önem verildiğinin hissettirilmesi ve ayrıca duygusal emeğin olumsuz sonuçlarından daha az etkilenebilmek adına sektör terübesine sahip personelin istihdam edilmesi ile işe yabancılaşma sorununun önüne geçilebilir.

- Araştırmada psikolojik sermayeye sahip çalışanların samimi davranışlar sergiledikleri ve işe yabancılaşma düzeylerinin düşük olduğu bulgusu elde edilmiştir. Mevcut çalışanların psikolojik sermaye düzeylerinin arttırılmasına yönelik psikolojik sermaye müdehale eğitimleri düzenlenebilir. Psikolojik sermaye müdehale eğitimi ile çalışanların sahip olduğu psikolojik kaynakların arttırıl- 
masıyla yüzeysel davranış ve derinlemesine davranış sergilemelerinin önüne geçilerek, çalışanların samimi davranışlar sergilenmesi sağlanabilir ve bu sayede işe yabancılaşmalarının önüne geçilebilir.

- Duygusal emek, işe yabancılaşma ve psikolojik sermayenin birlikte ele alınarak hizmet sektörünün emek yoğun özellik taşıyan değişik meslek gruplarında (bankacılık, sigortacılık, uçuş görevlileri, sağlık çalışanları vb.) çalışan katılımcı gruplarıyla yapılacak benzer çalışmalar ile daha genelleyici sonuçlar alınmasına yardımcı olabileceği düşünülmektedir.

$\mathrm{Bu}$ çalışma temel olarak, otel işletmelerindeki çalışanların sahip oldukları psikolojik sermaye düzeylerinin duygusal emek ile işe yabancılaşma ilişkisinde düzenleyici etkisini belirlemek amacıyla yapılmıştır. Araştırmada elde edilen sonuçlar ve öneriler doğrultusunda bu çalışmanın, otelcilik sektöründeki insan kaynağının öneminin daha iyi anlaşılabilmesi ve etkin bir şekilde yönetilebilmesine katkı sağlayacağı düşünülmektedir.

$\mathrm{Bu}$ araştırmanın en önemli kısıtı, araştırmanın sadece otel işletmelerinde yapılmış olmasıdır. Bundan sonra benzeri çalışmaların farklı sektörlerde ve farklı özelliklere sahip çalışanlar üzerinde yapılmasının araştırma sonuçlarının teyidi açısından önem taşımaktadır. 
EXTENDED ABSTRACT

\section{The Moderating Role of Psychological Capital in The Relationship Between Emotional Labor an Work Alienation

\author{
* \\ Hüseyin Aslan - İbrahim Sani Mert \\ Osmaniye Korkut Ata University, Antalya Science University
}

The emotional labour, which is an emotion management process, has been defined as employees' presenting their emotions to the customer by controlling them according to the predetermined rules (Hochschild, 1983). Hochschild (1983), interpreting emotional labour as the commercialization of emotions for a fee, has considered the emotional labour as a play in which the service plays the role of stage, the customer is spectator and the employee plays a certain roles. However, it is very clear that occupational life is not a stage, and shaping emotions in a certain frame creates serious problems. Therefore, the employee, whose emotions, actions and expressions have been changed, thinks that his/her emotions are trying to be bought by the business. This situation causes the employee to alienate to the work because s/he does not feel any freedom but feel himself/herself as alone and weak (Tokmak, 2014; Kaya and Serceoglu, 2013). In addition, although businesses consider employees' displaying the feelings that they do not indeed feel in accordance with the organizational representation rules as an element increasing the organisational performance, this leads to many negative consequences for the employees such as work alienation, job dissatisfaction, burnout, intention to leave of employment, stress and psychological disorders (Grandey, 2000, Tokmak, 2014, Begenirbas, 2015). Both removing these negative consequences for employees and employees' displaying the feelings that they feel in terms of organisational performance by according them with the organizational representation rules could be possible with the increase in the psychological capital of the employees. When considering the effect of emotional labour on the psychological states of individuals from this point of view, it is thought that 
employees' having high levels of psychological capital could provide positive contributions against the problems to be created by the affective disharmony originating from the emotional labour.

The goal of this study is to determine whether the emotional labour, of which importance is increasing in the fierce competition environment day by day, is a variable affecting the work alienation of the employees and to investigate whether the psychological capital levels of the employees has a moderator effect on the relationship between the emotional labour and the work alienation.

It was found out that while displaying surface and deep acting affected the work alienation positively and significantly, genuine acting affected the work alienation negatively according to the findings obtained from the study. These results are in parallel to the ones achieved by Begenirbas (2015) and Celik and Atik (2016). It was detected that the emotional labour affected the work alienation positively and significantly. This result is in parallel with the ones achieved by Kaya and Serceoglu (2013) and Tokmak (2014). Hochschild (1983) stated the emotional labour as a play in which the service was characterised as the stage, employees as actors and customers as spectators with the use of emotions in working life.

The employee must now display surface or deep acting as requested by the business to be good at his/her work (Hochschild, 1983; Ashforth and Humphrey, 1993, Grandey, 2000). Accordingly, the employee must act with the emotions requested within the framework of the representation rules of the business instead of his/her own feelings. The necessity of the employee to act in line with the rules of representation rather than his/her own feelings leads to emotional dissonance. The emotional dissonance that the employee lives between his/her own feelings, thoughts and values and the requirements of his/her work leads him/her to not be able to make sense of his/her work, and thus the employee is alienated with himself/herself and his/her work.

According to the findings obtained from the relationship between the components of emotional labour and psychological capital, it was determined that surface acting affected the optimism negatively; deep acting affected the self- efficacy and resilience negatively; displaying genuine acting affected the hope, self- efficacy and resilience positively and signif- 
icantly. These results show parallelism with the ones obtained by Begenirbas (2015) and Tamer (2015). Employees with high levels of hope, self-efficacy, optimism and resilience have required ability, determination, and motivation to overcome the obstacles that they encounter in the road to success and have resiliency to cope with the difficulties (Snyder, 2000 and Luthans et al., 2007a). Therefore, it can be evaluated that as indicated by Tamer (2015) and Hur et al. since the employees with high levels of hope, self-efficacy, optimism and resilience have the power to be able to cope with many problems physically and mentally and have the ability of organising the actions to activate the cognitive sources before any difficulty, the employees would not be affected by the negative outputs of the emotional labour by displaying deep acting through the achievements that they obtained thanks to the hope, self-efficacy, optimism and resilience instead of displaying the feelings that they do not feel through surface acting.

As a result of the analyses conducted for the main purpose of this study, it was achieved that the psychological capital had a moderator role on the relationship between the emotional labour and the work alienation. The result is in parallel with the one obtained by Tokmak (2014). It can be evaluated that developing the psychological capital of the employees would reduce the problem of the work alienation originating from the emotional labour, and thus the alienation of the employees would be prevented as a result of the affective disharmony that they live by displaying the feelings that they do not feel in line with the representation rules instead of the feelings that they feel.

It is also seen that both each of the components (hope, self-efficacy, optimism and resiliency) of psychological capital and the psychological capital itself, which is the total of above-mentioned components, provide a competitive advantage to the business with developing human resources and increasing performance (Luthans et al., 2010). Accordingly, it is suggested that businesses' conducting studies both to prevent the problem of work alienation originating from the emotional labour and to increase the psychological capital of the employee in terms of enhancing the customer satisfaction will lead to take positive conclusions. 


\section{Kaynakça / References}

Ashforth, B. E., ve Humphrey, R. H. (1993). Emotional labor in service roles: The influence of identity. Academy of management review, 18(1), 88-115.

Bandura, A. (1997). Self-efficacy: The exercise of control. New York: Macmillan.

Beğenirbaş, M. (2015). Psikolojik sermayenin çalışanların duygu gösterimleri ve işe yabancılaşmalarına etkileri: Sağlık sektöründe bir araştırma. Süleyman Demirel Üniversitesi İktisadi ve İdari Bilimler Fakültesi Dergisi, 20(3), 249-263.

Beğenirbaş, M., ve Çalışkan, A. (2014). Duygusal emeğin iş performansı ve işten ayrılma niyetine etkisinde kişilerarası çarpıklığın aracılık rolü. Business and Economics Research Journal, 5(2), 109-127.

Beğenirbaş, M., ve Turgut, E. (2016). Psikolojik sermayenin çalışanların yenilikçi davranışlarına ve performanslarına etkileri: Savunma sektöründe bir araştırma. Dokuz Eylül Üniversitesi İktisadi ve İdari Bilimler Fakültesi Dergisi, 31(1), 57-93.

Brook, P. (2009). The alienated heart: hochschild's 'emotional labour' thesis and the anticapitalist politics of alienation. Capital $\mathcal{E}$ Class, 33(2), 7-31.

Chu, K. H. L., ve Murrmann, S. K. (2006). Development and validation of the hospitality emotional labor scale. Tourism Management, 27(6), 1181-1191.

Çelik, M., ve Atik, S.(2016). Duygusal emek gösteriminin çalışanlar açısından sonuçları: Seyahat acentalarına yönelik bir araştırma. Akademik Sosyal Araştırmalar Dergisi, 4(36), 507-521.

Çelik, M., ve Yıldız, B. (2016). Duygusal emek düzeyinin işten ayrılma niyeti üzerindeki etkisinde stresin aracı rolü. Journal of International Social Research, 9(45),734-745.

Dahling, J. J., ve Perez, L. A. (2010). Older worker, different actor? Linking age and emotional labor strategies. Personality and Individual Differences, 48(5), 574-578.

Gassmann, J. N. N. (2010). Patrolling the homefront: The emotional labor of Army wives volunteering in family readiness groups. Unpublished doctoral dissertation, University of Kansas, Kansas. 
Ghalandari, K. ve M. G. G. Jogh (2012), The effect of emotional labor strategies (surface acting and deep acting) on job satisfaction and job burnout in rranian organizations: the role of emotional intelligence. Interdisciplinary Journal of Research in Business, 1(12), 24-31.

Goffman, E. (1959). The presentation of self in everyday life. Garden City, NY: Double Day.

Hochschild, A. R. (1979). Emotion work, feeling rules, and social structure. American Journal of Sociology, 85(3), 551-575.

Hochschild, A. R.(1983). The managed heart: Commercialization of human feeling. Berkeley, CA: University of California Press.

Hur, W. M., Rhee, S. Y., ve Ahn, K. H. (2016). Positive psychological capital and emotional labor in Korea: the job demands-resources approach. The International Journal of Human Resource Management, 27(5), 477-500.

Kaya, U. ve Serçeoğlu, N. (2013). Duygu işçilerinde işe yabancılaşma: Hizmet sektöründe bir araştırma, Çalı̧̧ma ve Toplum, 36(1), 311-346

Kızanlıklı, M. (2014). Otel işletmelerinde duygusal emek öncüllerinin belirlenmesine yönelik bir araştırma.Yayımlanmamış doktora tezi, Gazi Üniversitesi,SBE , Ankara.

Luthans, F. (2002). The need for and meaning of positive organizational behaviour. Journal of Organizational Behavior, 23(6), 695-706.

Luthans, F., Avey, J. B., Avolio, B. J. ve Peterson, S. J. (2010). The Development and Resulting Performance Impact of Positive Psychological Capital. Human Resource Development Quarterly. 21(1), 41-67.

Luthans, F., Avolio, B. J., Avey, J. B., ve Norman, S. M. (2007c). Positive psychological capital: Measurement and relationship with performance and satisfaction. Personnel Psychology, 60(3), 541-572.

Luthans, F., Youssef, C. M., and Avolio, B. J. (2007a). Psychological capital: developing the competitive edge. New York: Oxford University Press.

Martinez-Inigo, D., Totterdell, P., Alcover, C.M., ve Holman, D. (2007). Emotional labour and emotional exhaustion: Interpersonal and intrapersonal mechanisms,Work \& Stress,21(1), 30-47.

Masten, A. S. ve Reed, M-G. J. (2002). Resilience in development. In C. R. Snyder, ve S. Lopez (Ed.) Handbook of Positive Psychology (74-88). New York: Oxford University Press. 
Norman S., Luthans, B. ve Luthans, K. (2005). The proposed contagion effect of hopeful leaders on the resiliency of employees and organizations. Journal of Leadership and Organizational Studies. 12(2), 55-64.

Prentice, C., ve King, B. (2011). The influence of emotional intelligence on the service performance of casino frontline employees. Tourism and Hospitality Research, 11(1), 49-66.

Seligman, M. (1998). Learned optimism. New York, NY: Pocket Books.

Snyder, C. R. (2000). Handbook of hope: Theory, measures, and applications. San Diego: Academic press.

Snyder, C. R., Harris, C., Anderson, J. R., Holleran, S. A., Irving, L. M., Sigmon, S. T.,...,Harney, P. (1991). The will and the ways: Development and validation of an individual-differences measure of hope. Journal of personality and social psychology, 60(4), 570.

Tamer, I. (2015). The effect of positive psychological capital on emotional labor. International Journal of Research in Business and Social Science, $4(2), 20-34$.

Tokmak, İ. (2014). Duygusal emek ile işe yabancılaşma ilişkisinde psikolojik sermayenin düzenleyici etkisi. İşletme Araştırmaları Dergisi, 6(3),134-156.

Türk, M., ve Kara, E. (2018). Genç lider yöneticilerin inovasyon anlayışı: Turizm sektörü üzerine bir alan araştırması. OPUS Uluslararası Toplum Araştırmaları Dergisi, 8(1), 108-124.

Yıldız, B., ve Çetindaş, A. (2018). Stratejik kaynak kullanımının firma performansı üzerindeki etkisinde tedarik zinciri çevikliğinin aracı rolü. BMIJ, 6(4), 878-897.

\section{Kaynakça Bilgisi / Citation Information}

Aslan, H. ve Mert, S.İ. (2019). Duygusal emek ile işe yabancılaşma ilişkisinde psikolojik sermayenin düzenleyici rolü. OPUS-Uluslararası Toplum Araştırmaları Dergisi, 11(18), 1736-1772. DOI: 10.26466/opus. 